\title{
The sexual and reproductive health and rights of young people in India: A review of the situation
}

\author{
K.G. Santhya \\ Population Council \\ Shireen J. Jejeebhoy \\ Population Council
}

Follow this and additional works at: https://knowledgecommons.popcouncil.org/departments_sbsr-pgy

Part of the Demography, Population, and Ecology Commons, Family, Life Course, and Society Commons, and the International Public Health Commons How does access to this work benefit you? Let us know!

\section{Recommended Citation}

Santhya, K.G. and Shireen J. Jejeebhoy. 2012. "The sexual and reproductive health and rights of young people in India: A review of the situation." New Delhi: Population Council. 

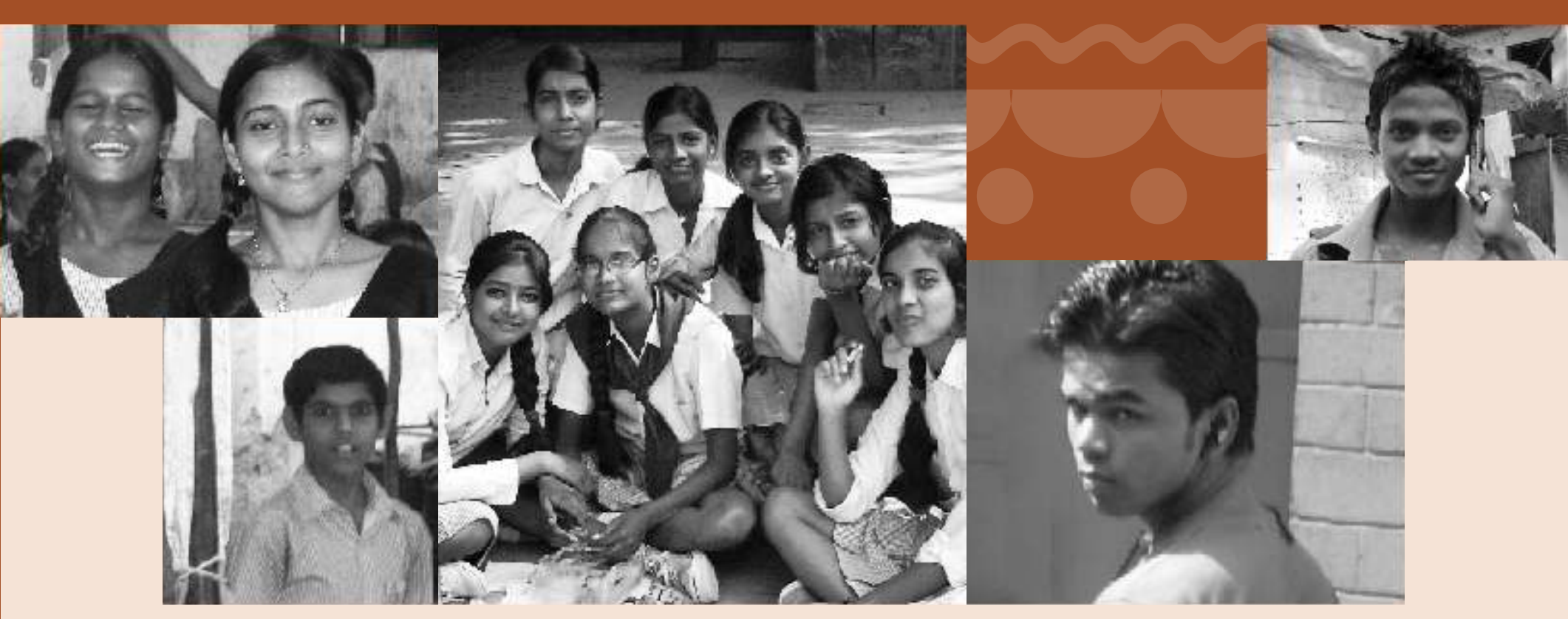

\section{The sexual and reproductive health and rights of young people in India: A review of the situation}


This paper synthesises the evidence on sexual and reproductive health situation of young people in India, sheds light on those sub-populations of young people who are most vulnerable to adverse sexual and reproductive outcomes, and assesses the barriers that compromise the sexual and reproductive health and rights of young people at the individual and family levels, as well as at the programme delivery level.

For additional copies of this report, please contact:

Population Council

Zone 5-A, Ground Floor

India Habitat Centre

Lodi Road

New Delhi -110003

Phone: 011-2464 2901/02

Email: info-india@popcouncil.org

Web site: http://www.popcouncil.org/asia/india/html

The Population Council is an international, non-profit, non-governmental organisation that seeks to improve the well-being and reproductive health of current and future generations around the world and to help achieve a humane, equitable and sustainable balance between people and resources. The Council conducts biomedical, social science and public health research, and helps build research capacities in developing countries.

\section{Copyright $\odot 2012$ Population Council}

Suggested citation: Santhya, K. G. and S. J. Jejeebhoy. 2012. The sexual and reproductive health and rights of young people in India: A review of the situation. New Delhi: Population Council. 


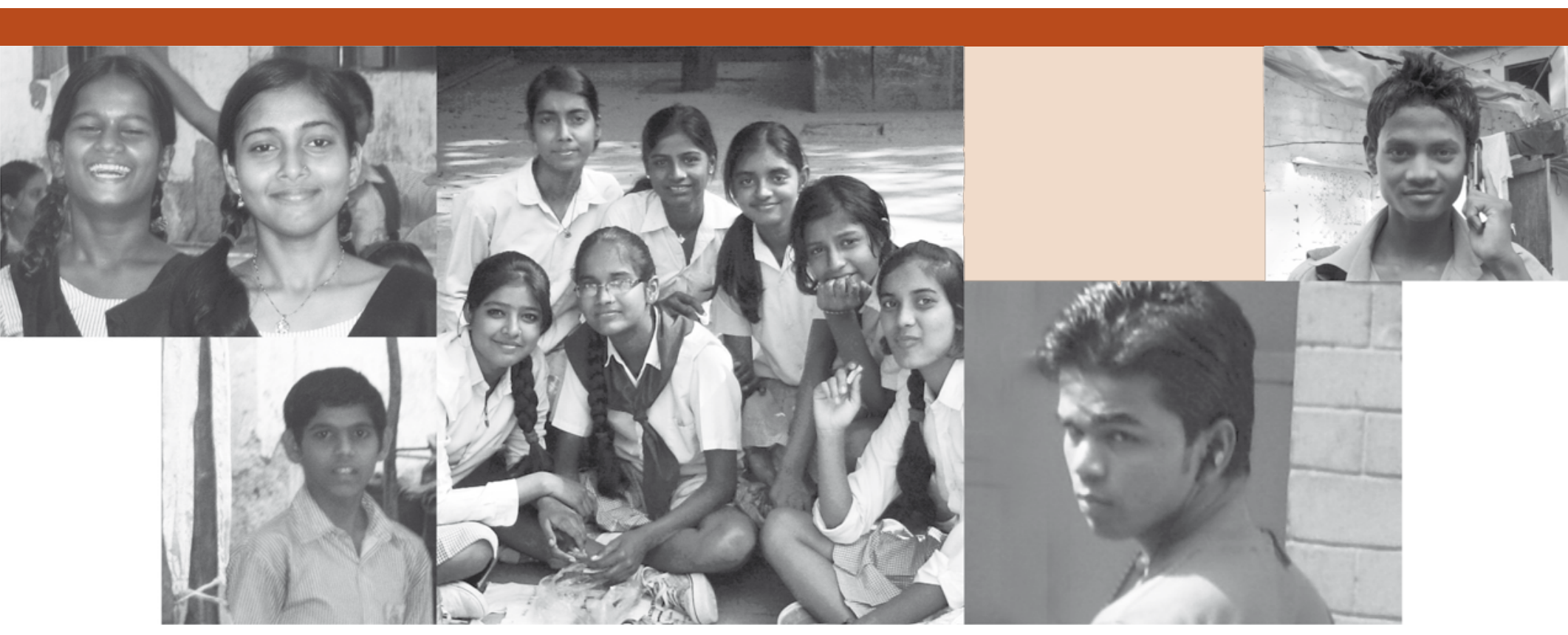

\section{The sexual and reproductive health and rights of young people in India: A review of the situation}

K G Santhya

Shireen J Jejeebhoy 



\section{Contents}

Chapter 1: Introduction 1

$\begin{array}{ll}\text { Methodology } & 1\end{array}$

Chapter 2: Sexual and reproductive health situation of young people 2

Early entry into sexual life $\quad 2$

Unsafe, unprotected or forced sexual relations $\quad 4$

$\begin{array}{ll}\text { Multiple partner relations } & 4\end{array}$

$\begin{array}{ll}\text { Contraceptive use } & 6\end{array}$

$\begin{array}{lr}\text { Unwanted and forced sex } & 10\end{array}$

$\begin{array}{ll}\text { Childbearing in childhood } & 10\end{array}$

Unplanned pregnancy and abortion $\quad 14$

RTIs/STIs and HIV 20

$\begin{array}{ll}\text { Malnutrition } & 20\end{array}$

Chapter 3: Challenges in meeting youth sexual and reproductive health needs and rights 21

Individual-level barriers $\quad 21$

Limited awareness of health-promoting behaviours $\quad 21$

$\begin{array}{ll}\text { Limited health care seeking practices } & 22\end{array}$

Gender power imbalances and limited female agency 28

Lack of social support $\quad 31$

Family-level barriers $\quad 32$

Systemic challenges $\quad 34$

Unmet need in educating the young 34

Uneven and poor implementation of programmes intended to raise awareness of sexual and

reproductive matters $\quad 34$

Outstanding issues in the implementation of programmes to empower girls 35

Health system limitations 35

Limited attempts at engaging boys and young men 36

Insufficient attention to reach the most vulnerable and the marginalised 36

Weak enforcement of laws and acts 37

Difficulties in breaking down patriarchal norms held by key influentials in the community 38

Chapter 4: Summary

\begin{tabular}{lr} 
References & 41 \\
\hline
\end{tabular}

$\begin{array}{ll}\text { Authors } & 44\end{array}$ 


\section{List of tables}

Table 2.1 Percentage of youth who had engaged in pre-marital sex in adolescence ${ }^{*}$

by background characteristics, six states, 2006-07

Table 2.2 Percentage of youth who had pre-marital sex reporting multiple partnerships by background characteristics, six states, 2006-07

Table 2.3 Percentage of youth who had pre-marital sex reporting consistent condom use by background characteristics, six states, 2006-07

Table 2.4 Percentage of married young women currently using any contraceptive method and any non-terminal modern method, according to state, India, 2005-06

Table 2.5 Percentage of married young women currently using any contraceptive method and any non-terminal modern method by background characteristics, India, 2005-06

Table 2.6 Percentage of women aged 20-24 who had given birth before age 18 and married women aged 15-24 with three or more children by background characteristics, India, 2005-06

Table 2.7 Percentage of unplanned births to married young women aged 15-24 in the five years preceding the NFHS-3 by background characteristics, India, 2005-06

Table 2.8 Percentage of youth who were moderately or severely anaemic, according to state, India, 2005-06

Table 2.9 Percentage of youth who were moderately or severely anaemic by background characteristics, India, 2005-06

Table 3.1 Awareness of sexual and reproductive health matters among youth aged 15-24, six states, 2006-07

Table 3.2 Percentage of youth who had comprehensive awareness of HIV/AIDS by background characteristics, six states, 2006-2007

Table 3.3 Percentage of married young women with an unmet need for contraceptives by background characteristics, India, 2005-06

Table 3.4 Among infants born to young women in the five years preceding the NFHS-3, percentage whose mother received maternal health services, according to state, India, 2005-06

Table 3.5 Among infants born to young women in the five years preceding the NFHS-3, percentage whose mother received maternal health services by background characteristics, India, 2005-06

Table 3.6 Percentage of young women reporting exercise of agency by background characteristics, six states, 2006-07

Table 3.7 Differences in indicators of young people's agency, SRH awareness and SRH practices by economic and educational vulnerability, six states, 2006-07 


\section{List of figures}

Figure 2.1 Percentage of 20-24 year-old women married by age 18, according to state, India, 2005-06

Figure 2.2 Percentage of 20-24 year-old women married by age 18 by selected background characteristics, India, 2005-06

Figure 2.3 Percentage of married young women who had experienced marital sexual violence by background characteristics, six states, 2006-07

Figure 2.4 Percentage of women aged 20-24 who had given birth before age 18, according to state, India, 2005-06

Figure 2.5 Percentage of married women aged 15-24 with three or more children, according to state, India, 2005-06

Figure 2.6 Percentage of unplanned births to married young women aged 15-24 in the five years preceding the NFHS-3, according to state, India, 2005-06

Figure 3.1 Percentage of married young women with an unmet need for contraceptives, according to state, India, 2005-06

Figure 3.2 Percentage of youth reporting discomfort about accessing SRH services from health care providers, six states, 2006-07

Figure 3.3 Percentage of youth reporting communication about sensitive matters with their mother or father, six states, 2006-07

Figure 3.4 Access to formal life skills/sex education among married and unmarried young men and women, six states, 2006-07 


\section{Acknowledgements}

This review has benefitted hugely from the input of many. We are grateful to the Ford Foundation for support, which made this study possible. We would also like to acknowledge the insightful comments and suggestions of Vanita Nayak Mukherjee, Programme Officer, Ford Foundation, on a previous draft of this report. Her comments have been incorporated in this report and are gratefully acknowledged.

We are grateful to several colleagues for their support and insights as we prepared this review. Rajib Acharya and A.J. Francis Zavier extended invaluable support in analysing data presented in this review and providing suggestions and insights on the manuscript. M.A. Jose was responsible for conducting a search of the literature relating to our topic; his support and success in identifying many of the wide range of articles and papers included in this review are much appreciated. Jyoti Moodbidri edited the report and we thank her for both her technical and editorial inputs. Komal Saxena was responsible for preparing the figures included in this review, reviewing the manuscript and managing the preparation of this report; we are grateful to her for her meticulous attention to detail, which has made the report more readable and precise.

K G Santhya

Shireen J Jejeebhoy 


\section{CHAPTER 1}

\section{Introduction}

There are an estimated 358 million young people (aged 10-24 years) in India today (2011). Young people aged 10-24 comprise almost one-third (31 percent), and those aged 10-19 almost one-quarter (22 percent) of the nation's population (Office of the Registrar General and Census Commissioner, India, 2006). India's development depends on its commitment to and investment in its young people. The achievement of the Millennium Development Goals as well as the realisation of the demographic dividend and population stabilisation goals will depend, for example, on the quality of the transition that young people make to adulthood. Questions remain about the quality of this transition. While young people are healthier, more urbanised and better educated than earlier generations, and marry and have children later than in the past, they face significant risks related to sexual and reproductive health and many lack the power to make informed sexual and reproductive choices. These vulnerabilities and the factors influencing them are, however, poorly understood.

This paper summarises the sexual and reproductive health situation of young people in India, sheds light on those sub-populations of young people who are most vulnerable to adverse sexual and reproductive outcomes, and assesses the barriers that compromise the sexual and reproductive health and rights of young people at the individual and family levels, as well as at the health system level.

\section{Methodology}

In order to understand the sexual and reproductive health situation, and identify themes that are neglected, groups that are most vulnerable, and factors that compromise the sexual and reproductive health and rights of young people, our review relies on data from the most recent National Family Health Survey (NFHS-3) (International Institute for Population Sciences and Macro International, 2007) and the Youth in India: Situation and Needs study, a sub-national study of young people in six states (hereafter referred to as the Youth Study; International Institute for Population Sciences and Population Council, 2010). It also encompasses findings from extensive searches of published and unpublished, qualitative and quantitative studies referring to the situation of youth in India, undertaken over the last decade or so. 


\section{CHAPTER 2}

\section{Sexual and reproductive health situation of young people}

Evidence on the sexual and reproductive health situation of young people suggests that young people are vulnerable in many ways. Child marriage persists among young women, and pre-marital entry into sexual life is observed among men and a few young women. Also reflecting young peoples' vulnerability are adolescent childbearing, unsafe, unwanted or forced sexual relations, unplanned pregnancy and abortion, and the risk of reproductive tract infections (RTIs), HIV and other sexually transmitted infections (STIs). Malnutrition, particularly among young women, is widespread and deprives adolescents of the extra nutritional requirements to support their rapid growth during adolescence and places young women at risk of adverse reproductive health consequences.

\section{Early entry into sexual life}

Entry into sexual life occurs at a young age for many. Although India is committed to protecting adolescents from such harmful traditional practices as early marriage, and despite laws prohibiting marriage to young women before age 18 and to young men before age 21 , marriage continues to take place in adolescence for significant proportions of young women. While the age at marriage for women has undergone a secular increase, the reality is that almost half of all women aged 20-24 were married by 18 years as recently as in 2006 (International Institute for Population Sciences and Macro International, 2007). Indeed, trend data show that the percentage of women marrying by age 18 declined by just seven percentage points between 1992 and 2006 (Ministry of Health and Family Welfare, 2009a). While large proportions of young men were married before they were legally permitted to do so, just 10 percent were married before they were 18 .

State-wise differences were notable. In eight of the 29 states of India (Andhra Pradesh, Bihar, Chhattisgarh, Jharkhand, Madhya Pradesh, Rajasthan, Uttar Pradesh and West Bengal), between one-half and two-thirds of young women (54-69\%) were married by 18 years. In contrast, one in seven or fewer young women (12-15\%) were married as children in such states as Goa, Himachal Pradesh, Kerala, Jammu and Kashmir and Manipur (Figure 2.1).

Figure 2.2 provides evidence of wide disparities in marriage age: rural, poorly educated and economically disadvantaged young women and those from scheduled castes and tribes were considerably more likely than other women to have experienced early marriage. The starkest difference was by schooling; 77 percent of young women with no education were married before they were 18 , compared to just seven percent of those with 12 or more years of schooling.

While marriage marks the onset of sexual activity among the large majority of young women, there is growing evidence of pre-marital onset of sexual 
Figure 2.1: Percentage of 20-24 year-old women married by age 18, according to state, India, 2005-06

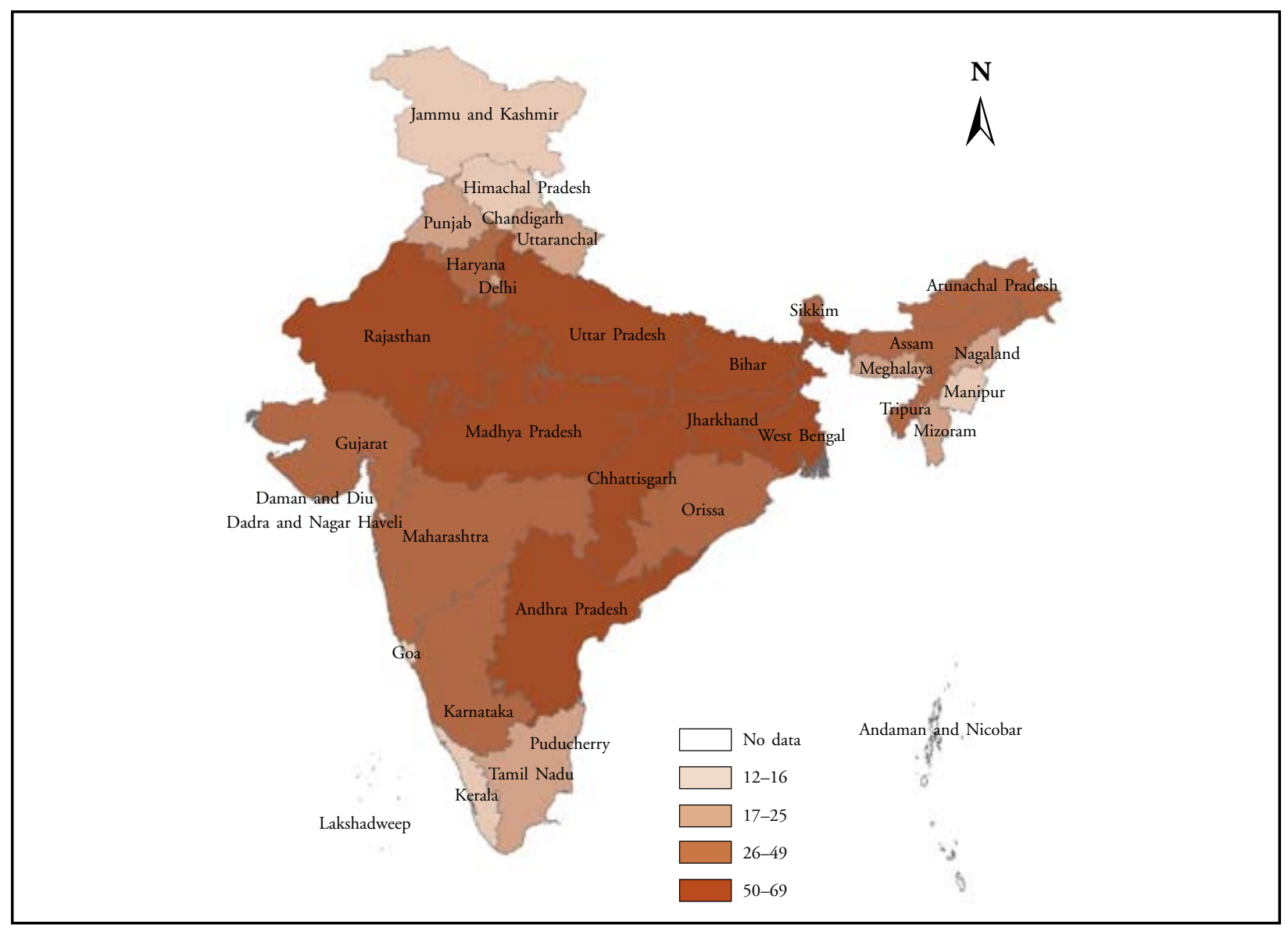

Source: Calculated from individual female respondent data from the NFHS-3.

activity in adolescence particularly among young men.

Evidence from the Youth Study shows that 11 percent of young men and five percent of young women aged 15-24 had engaged in pre-marital sex in adolescence, that is, before age $20^{1}$ (International Institute for Population Sciences and Population Council, 2010). Differentials are apparent, with rural young women twice as likely (6\% versus 3\%) and rural young men almost three times as likely (14\% versus $5 \%)$ to have experienced pre-marital sex in adolescence as their urban counterparts (Table 2.1). Differences were also apparent by other socioeconomic factors. For example, youth with 12 or more years of education were less likely than others to report the experience of pre-marital sex in adolescence (5\% versus $10-16 \%$ among young men and $1 \%$ versus $4-10 \%$ among young women). Young men and women in the poorest quintiles (first and second) were more likely than others to report such experience $(15-17 \%$ versus $6-11 \%$ among young men and $9-11 \%$ versus $2-7 \%$ among young women).

\footnotetext{
${ }^{1}$ Cumulative percentages of youth who experienced first pre-marital sex before age 20, calculated using life table techniques.
} 
Figure 2.2: Percentage of 20-24 year-old women married by age 18 by selected background characteristics, India, 2005-06

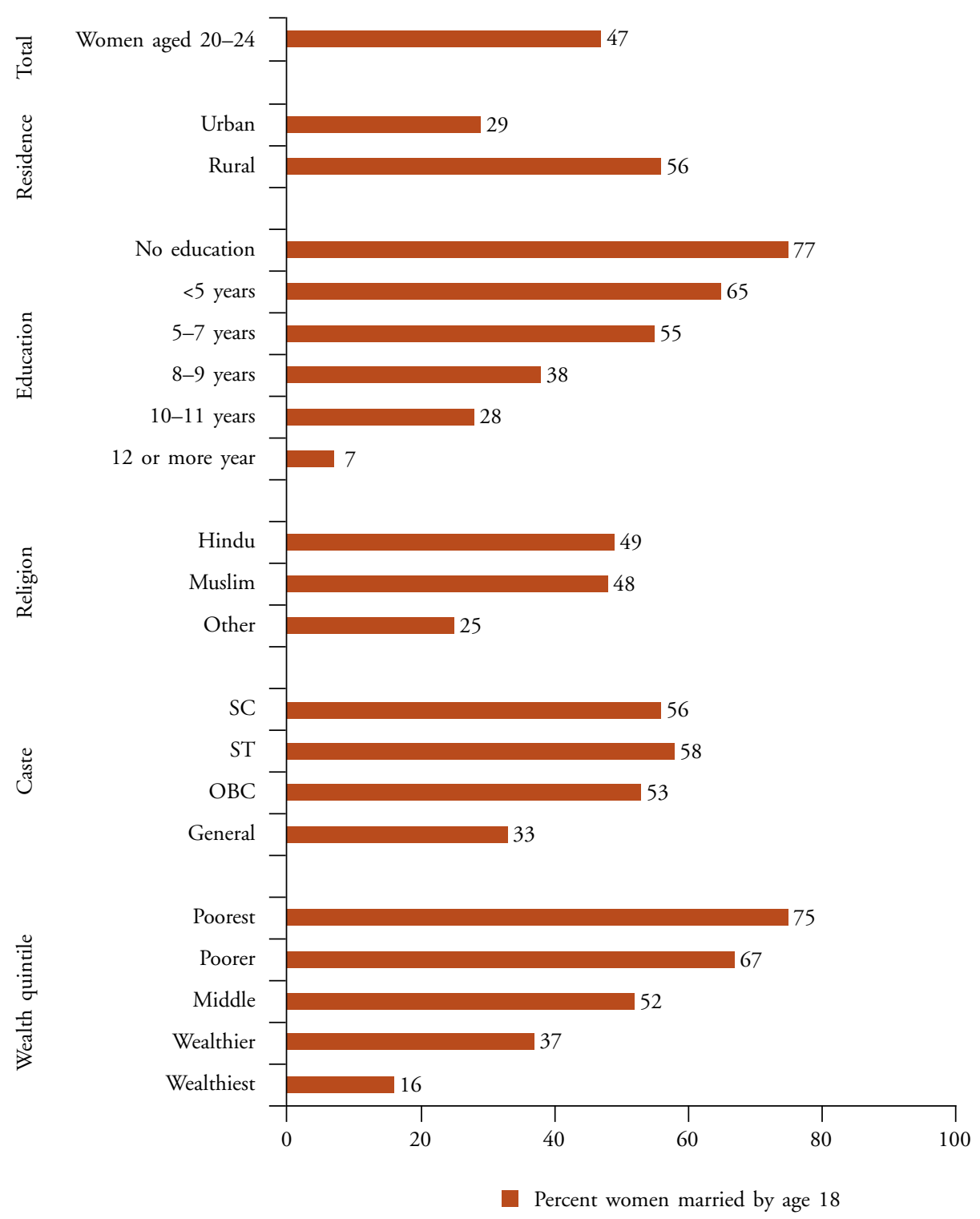

Source: Calculated from individual female respondent data from the NFHS-3.

\section{Unsafe, unprotected or forced sexual relations}

\section{Multiple partner relations}

Where sexual relations take place, they are often unsafe. For example, the Youth Study found that among young men and young women who reported the experience of pre-marital sex, 25 percent and 21 percent, respectively, had engaged in sex with more than one partner, with rural youth somewhat more likely than their urban counterparts to report so (International Institute for Population Sciences and Population Council, 2010). 


\section{Table 2.1}

Percentage of youth who had engaged in pre-marital sex in adolescence* by background characteristics, six states, 2006-07

\begin{tabular}{|c|c|c|}
\hline Background characteristics & $\begin{array}{c}\text { Men } \\
\text { 15-24 years }\end{array}$ & $\begin{array}{c}\text { Women } \\
\text { 15-24 years }\end{array}$ \\
\hline \multicolumn{3}{|l|}{ Residence } \\
\hline Urban & 5.1 & 2.5 \\
\hline Rural & 13.7 & 6.4 \\
\hline \multicolumn{3}{|l|}{ Education } \\
\hline No education & 12.5 & 8.1 \\
\hline$<5$ years complete & 13.1 & 9.7 \\
\hline 5-7 years complete & 15.5 & 7.7 \\
\hline 8-9 years complete & 14.4 & 5.0 \\
\hline 10-11 years complete & 9.8 & 4.0 \\
\hline 12 or more years complete & 4.9 & 0.9 \\
\hline \multicolumn{3}{|l|}{ Religion } \\
\hline Hindu & 10.7 & 4.8 \\
\hline Muslim & 8.9 & 2.9 \\
\hline Other & 19.3 & 8.2 \\
\hline \multicolumn{3}{|l|}{ Caste/tribe } \\
\hline Scheduled caste & 15.2 & 7.2 \\
\hline Scheduled tribe & 18.0 & 15.3 \\
\hline Other backward caste & 8.8 & 3.6 \\
\hline General caste & 8.9 & 2.8 \\
\hline \multicolumn{3}{|l|}{ Wealth index } \\
\hline Poorest & 17.0 & 11.2 \\
\hline Poorer & 15.3 & 8.6 \\
\hline Middle & 11.4 & 5.6 \\
\hline Wealthier & 9.7 & 3.2 \\
\hline Wealthiest & 5.6 & 2.1 \\
\hline Total & 11.0 & 5.0 \\
\hline
\end{tabular}

Source: Calculated from the Youth in India: Situation and Needs 2006-07 study; 'Cumulative percentages of youth who experienced first pre-marital sex in adolescence, calculated using life table techniques. 
Socio-demographic differentials in multiple partnerships were narrow among young men (Table 2.2). Among young women, however, engaging in multiple partnerships before marriage declined with age (24\% of $15-19$ year-olds versus $18 \%$ of $20-24$ year-olds). Differentials by religion and caste suggest that Muslim young women and those from general castes were less likely than others to have engaged in multiple pre-marital partnerships (14\% versus $21-22 \%$ and $11 \%$ versus $19-29 \%$, respectively). Moreover, those who had completed 10 or more years of schooling were less likely than others to report such partnerships $(12-13 \%$ versus 23-28\%) while those in the poorest quintiles (first and second) were more likely than others to report so $(24-31 \%$ versus $15-18 \%)$.

\section{Contraceptive use}

Contraceptive use is limited, in both pre-marital and marital relationships; just 27 percent of young men and seven percent of young women had ever used a condom, and even fewer-13 percent and three percent, respectively-had used a condom consistently (Santhya, Acharya and Jejeebhoy, 2011). Evidence of consistent condom use among youth engaged in pre-marital sex, presented in Table 2.3, indicates that differences were uniformly negligible for young women, which is not surprising given that just three percent of young women reported consistent condom use within pre-marital sexual relationships. Among young men, consistent condom use increased with age, education and wealth status; differentials by religion and caste were less consistent (Table 2.3).

Among the married too, NFHS-3 findings presented in Table 2.4, show that just 28 percent of young women aged 15-24 were practising contraception (see also Parasuraman et al., 2009). State-wise differentials show that current use of any method ranged from $12-13$ percent to 54 percent;

\section{Table 2.2}

Percentage of youth who had pre-marital sex reporting multiple partnerships by background characteristics, six states, 2006-07

\begin{tabular}{l|c|c|}
\hline Background characteristics & $\begin{array}{c}\text { Men } \\
\text { 15-24 years }\end{array}$ & $\begin{array}{c}\text { Women } \\
\text { 15-24 years }\end{array}$ \\
\hline Age (years) & & \\
\hline 15-19 & 21.0 & 24.3 \\
$20-24$ & 26.7 & 18.2 \\
\hline Residence & & \\
Urban & 20.3 & 15.9 \\
Rural & 25.5 & 22.9 \\
Education & & \\
No education & 19.6 & 22.6 \\
$<5$ years complete & 19.4 & 22.5 \\
5-7 years complete & 27.6 & 22.5 \\
$8-9$ years complete & 24.0 & 27.8 \\
10-11 years complete & 26.7 & 11.9 \\
12 or more years complete & 24.0 & 13.0 \\
\hline
\end{tabular}


Table 2.2: (Cont'd)

\begin{tabular}{|l|c|c|}
\hline Background characteristics & $\begin{array}{c}\text { Men } \\
\text { 15-24 years }\end{array}$ & $\begin{array}{c}\text { Women } \\
\text { 15-24 years }\end{array}$ \\
\hline Religion & & \\
\hline Hindu & 25.0 & 21.9 \\
\hline Muslim & 19.7 & $(14.0)$ \\
\hline Other & 23.6 & 21.4 \\
\hline Caste/tribe & & \\
\hline Scheduled caste & 25.9 & 19.3 \\
\hline Scheduled tribe & 26.5 & 29.0 \\
\hline Other backward caste & 21.7 & 22.5 \\
\hline General caste & 26.7 & 10.8 \\
\hline Wealth index & & \\
Poorest & 26.5 & 31.0 \\
Poorer & 25.3 & 23.5 \\
Middle & 23.0 & 14.8 \\
\hline Wealthier & 23.0 & 16.0 \\
Wealthiest & 25.4 & 18.3 \\
\hline Total & $\mathbf{2 5 . 0}$ & $\mathbf{2 1 . 0}$ \\
\hline
\end{tabular}

Source: International Institute for Population Sciences and Population Council, 2010; () based on 25-49 unweighted cases.

indeed, fewer than one in five young women were currently practising contraception in seven of the 29 states (Bihar, Chhattisgarh, Jharkhand, Meghalaya, Nagaland, Orissa and Rajasthan) (Table 2.4).

Table 2.4 further shows that despite their young age, the use of non-terminal modern methods among married young women is limited; just 11 percent were using a non-terminal modern method (that is, just about two-fifths of young women who were currently practicing contraception). The use of non-terminal modern methods was as low as five percent or less in states such as Andhra Pradesh, Bihar and Karnataka, and above 20 percent in such states as Delhi, Mizoram, Punjab, Sikkim, Tripura and West Bengal.
Socio-demographic differentials in current contraceptive practice were notable: adolescent girls, and rural, poorly educated and economically disadvantaged young women were less likely than others to have used contraception within marriage (Table 2.5). For example, adolescent girls were only one-third as likely as young women (20-24 yearolds) to practise contraception (13\% versus 33\%). Likewise, rural, poorly educated and economically disadvantaged young women were less likely than others to have used some contraceptives. For example, young women from the poorest households were only half as likely as those from the richest households to do so (20\% versus $39 \%)$. As in the case of the current use of any method, sociodemographic differentials were evident in current use 
Table 2.3

Percentage of youth who had pre-marital sex reporting consistent condom use by background characteristics, six states, 2006-07

\begin{tabular}{|c|c|c|}
\hline Background characteristics & $\begin{array}{c}\text { Men } \\
\text { 15-24 years }\end{array}$ & $\begin{array}{l}\text { Women } \\
\text { 15-24 years }\end{array}$ \\
\hline \multicolumn{3}{|l|}{ Age (years) } \\
\hline $15-19$ & 8.0 & 3.1 \\
\hline $20-24$ & 15.8 & 1.9 \\
\hline \multicolumn{3}{|l|}{ Residence } \\
\hline Urban & 21.2 & 1.9 \\
\hline Rural & 10.6 & 2.7 \\
\hline \multicolumn{3}{|l|}{ Education } \\
\hline No education & 3.2 & 1.0 \\
\hline$<5$ years complete & 11.1 & 2.2 \\
\hline 5-7 years complete & 9.8 & 4.0 \\
\hline 8-9 years complete & 14.5 & 3.1 \\
\hline 10-11 years complete & 14.3 & 1.0 \\
\hline 12 or more years complete & 18.4 & 2.9 \\
\hline \multicolumn{3}{|l|}{ Religion } \\
\hline Hindu & 11.9 & 2.1 \\
\hline Muslim & 14.6 & (2.3) \\
\hline Other & 19.5 & 4.3 \\
\hline \multicolumn{3}{|l|}{ Caste/tribe } \\
\hline Scheduled caste & 12.8 & 1.7 \\
\hline Scheduled tribe & 8.9 & 4.2 \\
\hline Other backward caste & 11.3 & 2.4 \\
\hline General caste & 19.1 & 2.0 \\
\hline \multicolumn{3}{|l|}{ Wealth index } \\
\hline Poorest & 6.8 & 3.7 \\
\hline Poorer & 5.3 & 2.7 \\
\hline Middle & 11.4 & 2.3 \\
\hline Wealthier & 19.1 & 0.6 \\
\hline Wealthiest & 21.3 & 3.2 \\
\hline Total & 13.0 & 3.0 \\
\hline
\end{tabular}

Source: International Institute for Population Sciences and Population Council, 2010; () based on 25-49 unweighted cases. 
Table 2.4

Percentage of married young women currently using any contraceptive method and a modern non-terminal method, according to state, India, 2005-06

\begin{tabular}{|c|c|c|}
\hline State & Any method & $\begin{array}{l}\text { Any non-terminal } \\
\text { modern method }\end{array}$ \\
\hline India & 27.5 & 10.5 \\
\hline North & 24.3 & 14.4 \\
\hline Delhi & 35.4 & 25.1 \\
\hline Haryana & 31.0 & 17.8 \\
\hline Himachal Pradesh & 34.2 & 18.6 \\
\hline Jammu \& Kashmir & 22.2 & 13.1 \\
\hline Punjab & 33.8 & 24.1 \\
\hline Rajasthan & 17.8 & 9.0 \\
\hline Uttaranchal & 23.7 & 15.9 \\
\hline Central & 22.0 & 8.7 \\
\hline Chhattisgarh & 17.6 & 6.2 \\
\hline Madhya Pradesh & 20.3 & 7.6 \\
\hline Uttar Pradesh & 23.1 & 9.5 \\
\hline East & 28.1 & 11.9 \\
\hline Bihar & 12.6 & 4.0 \\
\hline Jharkhand & 15.5 & 7.0 \\
\hline Orissa & 19.0 & 10.3 \\
\hline West Bengal & 53.9 & 23.2 \\
\hline Northeast & 39.2 & 17.3 \\
\hline Arunachal Pradesh & 28.4 & 18.1 \\
\hline Assam & 40.0 & 15.4 \\
\hline Manipur & 37.9 & 14.3 \\
\hline Meghalaya & 15.7 & 9.4 \\
\hline Mizoram & 24.7 & 22.7 \\
\hline Nagaland & 12.1 & 6.5 \\
\hline Sikkim & 35.5 & 25.7 \\
\hline Tripura & 55.6 & 34.7 \\
\hline West & 32.1 & 14.3 \\
\hline Goa & 25.6 & 14.2 \\
\hline Gujarat & 34.0 & 14.1 \\
\hline Maharashtra & 31.2 & 14.4 \\
\hline South & 31.1 & 4.8 \\
\hline Andhra Pradesh & 33.6 & 1.8 \\
\hline Karnataka & 30.8 & 5.1 \\
\hline Kerala & 33.0 & 14.9 \\
\hline Tamil Nadu & 25.5 & 6.6 \\
\hline
\end{tabular}

Source: Calculated from individual female respondent data from the NFHS-3. 
of any modern non-terminal method. Adolescent girls were only half as likely as young women to use such methods ( $6 \%$ versus $12 \%$ ). Moreover, rural, poorly educated and economically disadvantaged young women were less likely than others to have used a non-terminal modern method. For example, young women with no education and those belonging to the most economically disadvantaged households were only one-fifth as likely as their counterparts with 12 or more years of schooling and belonging to the wealthiest households to use a nonterminal modern method (5\% versus $26 \%$ and $5 \%$ versus $25 \%$ ).

\section{Unwanted and forced sex}

Unwanted and forced sex is observed in both premarital and marital relations. While evidence from pre-marital relations is sparse, findings of the Youth Study have shown that as many as 18 percent of young women (and 3\% of young men) had been forced to engage in sex, and 15 percent of young women (and 3\% of young men) reported that they had been persuaded by their partner, against their will, to engage in sex (International Institute for Population Sciences and Population Council, 2010).

Married young women were also likely to face sexual violence. Evidence from the Youth Study indicates that almost one-third (32\%) of married young women had ever experienced sexual violence perpetrated by their husband (International Institute for Population Sciences and Population Council, 2010). Sexual violence within marriage also varied by region: it was more common in northern states (40-54\%) than in the western state of Maharashtra and the southern states (10-27\%). Differences by socio-demographic characteristics were notable: as illustrated in Figure 2.3, young women in rural areas, with no or limited education and those belonging to economically disadvantaged households were more likely than their counterparts to report marital sexual violence. For example, 42 percent of young women with no education compared to 16 percent with 12 or more years of schooling so reported.

\section{Childbearing in childhood}

Childbearing is initiated early: one in five young women aged 20-24 had their first baby before they were 18 years of age (International Institute for Population Sciences and Macro International, 2007). In five of the 29 states of India, over a quarter and close to two-fifths of young women (28-37\%) had their first birth by age 18 (Andhra Pradesh, Arunachal Pradesh, Bihar, Jharkhand and West Bengal) (Figure 2.4). In contrast in several states (Delhi, Goa, Himachal Pradesh, Jammu and Kashmir, Kerala, Punjab, Manipur, Tamil Nadu and Uttaranchal), fewer than one in ten young women (4-9\%) had their first birth before age 18.

Table 2.6 presents young women's experiences of early childbearing and multiple pregnancies by background characteristics. Findings indicate that rural young women were twice as likely as the urban to have their first birth by age 18 (13\% versus $33 \%)$. Differences by education, economic status and caste were striking, with less educated young women, those belonging to the most economically disadvantaged households and those belonging to scheduled tribes more likely than others to have given birth before they were 18 years of age. For example, 39 percent of young women with no education compared to one percent of those with 12 or more years of schooling had their first birth before age 18 .

At the same time, multiple pregnancies characterise the life of many young women; indeed, one in eight young women aged 20-24 had three or 
Table 2.5

Percentage of married young women currently using any contraceptive method and a modern non-terminal method by background characteristics, India, 2005-06

\begin{tabular}{|c|c|c|}
\hline Background characteristics & Any method & $\begin{array}{l}\text { Any non-terminal } \\
\text { modern method }\end{array}$ \\
\hline \multicolumn{3}{|l|}{ Age (years) } \\
\hline $15-19$ & 13.0 & 5.8 \\
\hline $20-24$ & 33.4 & 12.4 \\
\hline \multicolumn{3}{|l|}{ Residence } \\
\hline Urban & 35.0 & 18.3 \\
\hline Rural & 25.2 & 8.1 \\
\hline \multicolumn{3}{|l|}{ Education } \\
\hline No education & 21.1 & 4.8 \\
\hline$<5$ years complete & 30.5 & 9.6 \\
\hline 5-7 years complete & 30.0 & 10.7 \\
\hline 8-9 years complete & 32.5 & 13.8 \\
\hline 10-11 years complete & 32.1 & 17.5 \\
\hline 12 or more years complete & 35.9 & 25.6 \\
\hline \multicolumn{3}{|l|}{ Religion } \\
\hline Hindu & 27.1 & 9.8 \\
\hline Muslim & 28.6 & 13.6 \\
\hline Other & 38.0 & 15.7 \\
\hline \multicolumn{3}{|l|}{ Caste/tribe } \\
\hline Scheduled caste & 28.6 & 9.1 \\
\hline Scheduled tribe & 20.4 & 6.1 \\
\hline Other backward caste & 23.9 & 7.8 \\
\hline General & 33.2 & 16.8 \\
\hline \multicolumn{3}{|l|}{ Wealth index } \\
\hline Poorest & 19.8 & 4.7 \\
\hline Poorer & 24.4 & 6.8 \\
\hline Middle & 27.8 & 8.1 \\
\hline Wealthier & 32.3 & 14.7 \\
\hline Wealthiest & 38.7 & 25.2 \\
\hline Total & 28.0 & 11.0 \\
\hline
\end{tabular}

Source: Calculated from individual female respondent data from the NFHS-3. 
Figure 2.3: Percentage of married young women who had experienced marital sexual violence by background characteristics, six states, 2006-07

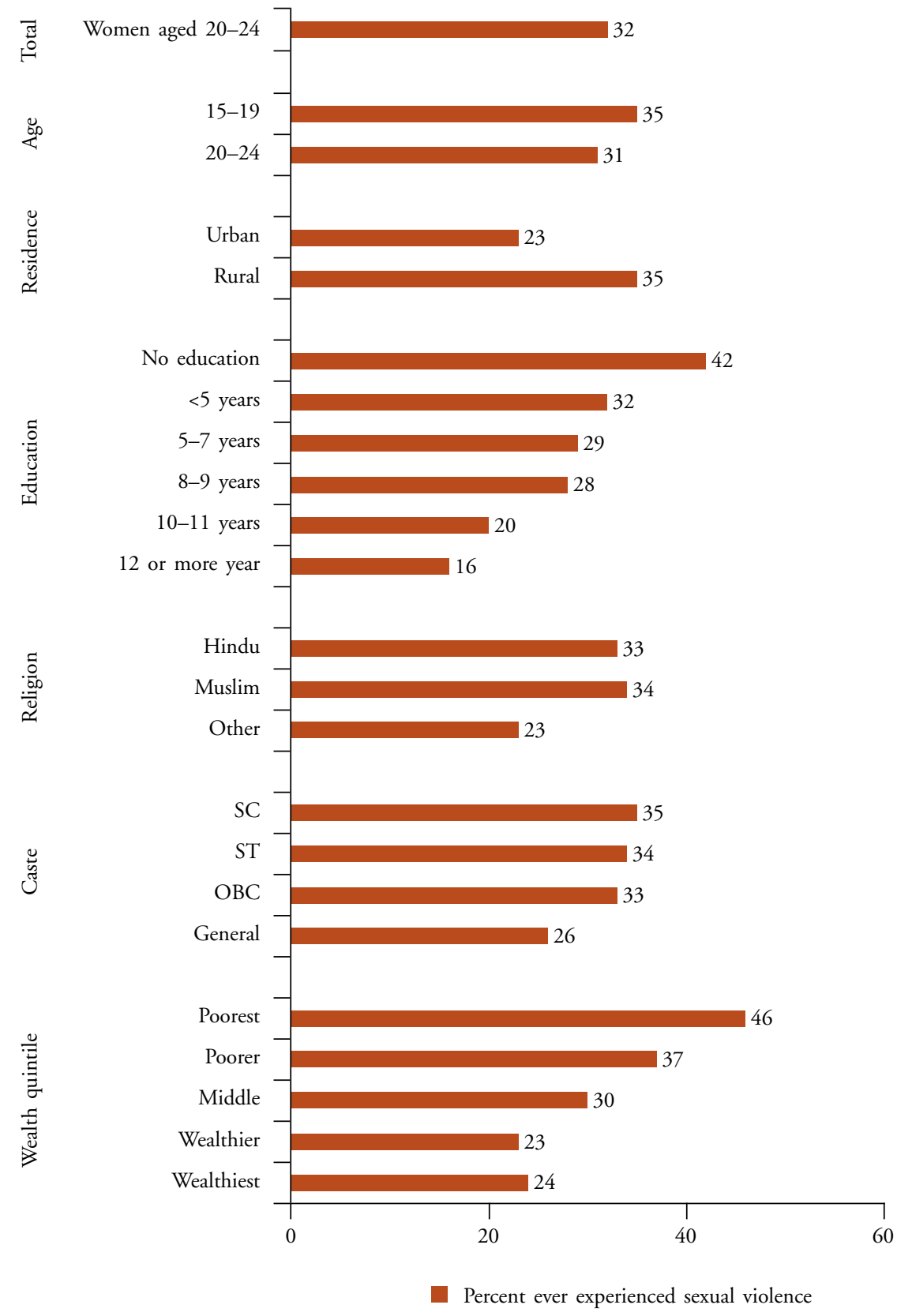

Source: International Institute for Population Sciences and Population Council, 2010.

more children (International Institute for Population Sciences and Macro International, 2007). In states like Arunachal Pradesh, Bihar, Chhattisgarh, Jharkhand, Karnataka, Nagaland, Rajasthan and Uttar Pradesh, 15-19 percent of young women had three or more children (Figure 2.5); in comparison 5 percent or fewer young women, fewer than 6 percent of young women had three or more children in such states as Goa, Kerala and Tamil Nadu (see Figure 2.5). Socio-demographic differentials were notable 
Figure 2.4: Percentage of women aged 20-24 who had given birth before age 18, according to state, India, 2005-06

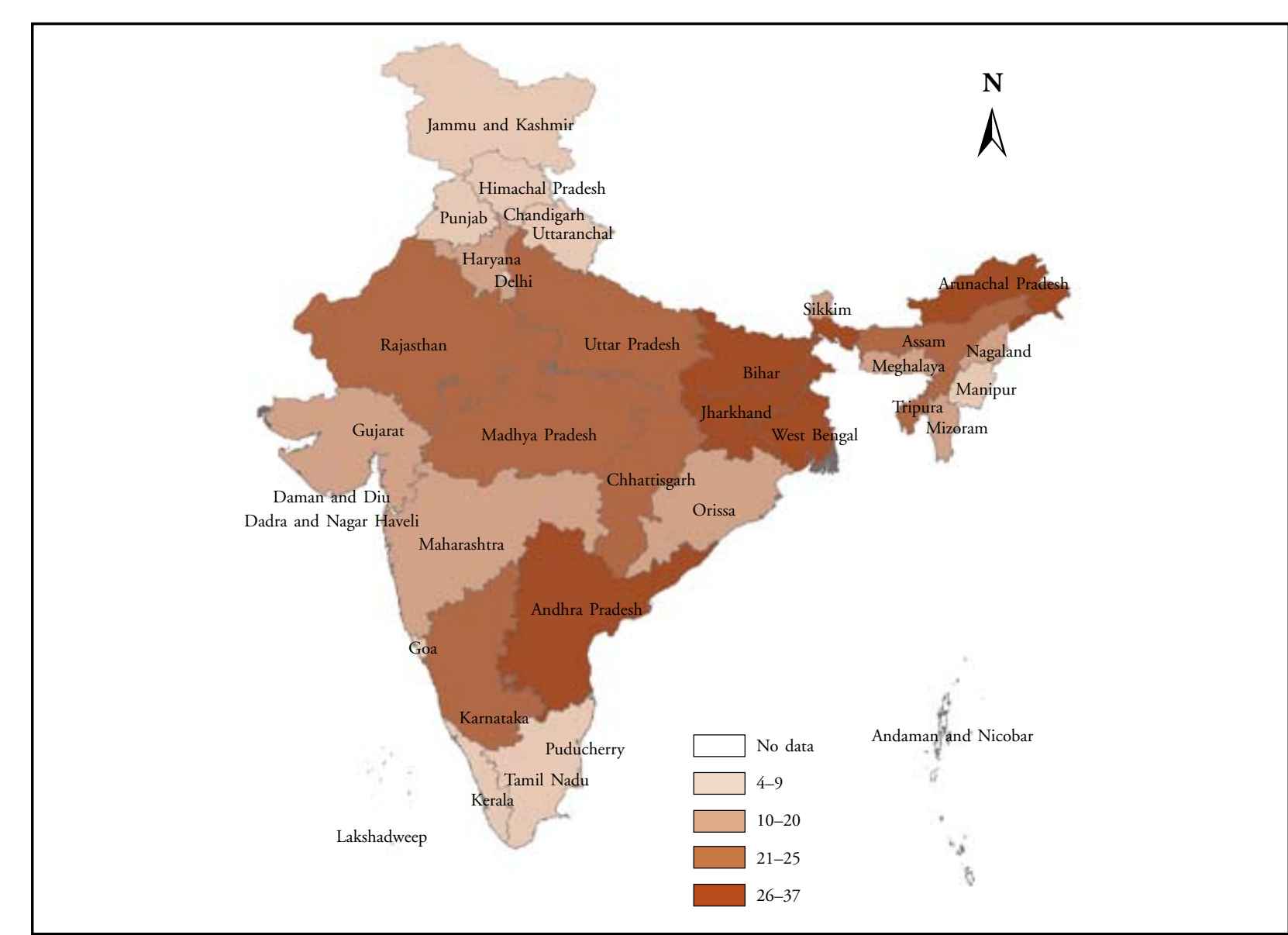

Source: Calculated from individual female respondent data from the NFHS-3.

with regard to the experience of multiple births as well (Table 2.6). Young women from rural areas, those from the poorest households, and those with limited amounts of education were more likely than others to have three or more children before they transitioned out of young adulthood. For example, 39 percent of young women with no education compered to 1 percent of these with 12 or more years of education had three or more children.

As a consequence, both maternal and neonatal mortality are higher among the young than among older women: 45 percent of all maternal deaths take place among those aged 15-24 (Office of the Registrar General, India, 2011) and neonatal mortality rates range from 54 per 1000 live births among those aged $15-19$ to 34 and 38, respectively, among those aged 20-29 and 30-39 (International Institute for Population Sciences and Macro International, 2007). Rural adolescents are particularly at risk, with neonatal mortality rates as high as 60/1000 (compared to 31 among urban adolescents).

While the majority of adolescent girls bear children within a marital relationship, pre-marital 
Figure 2.5: Percentage of married women aged 15-24 with three or more children, according to state, India, 2005-06

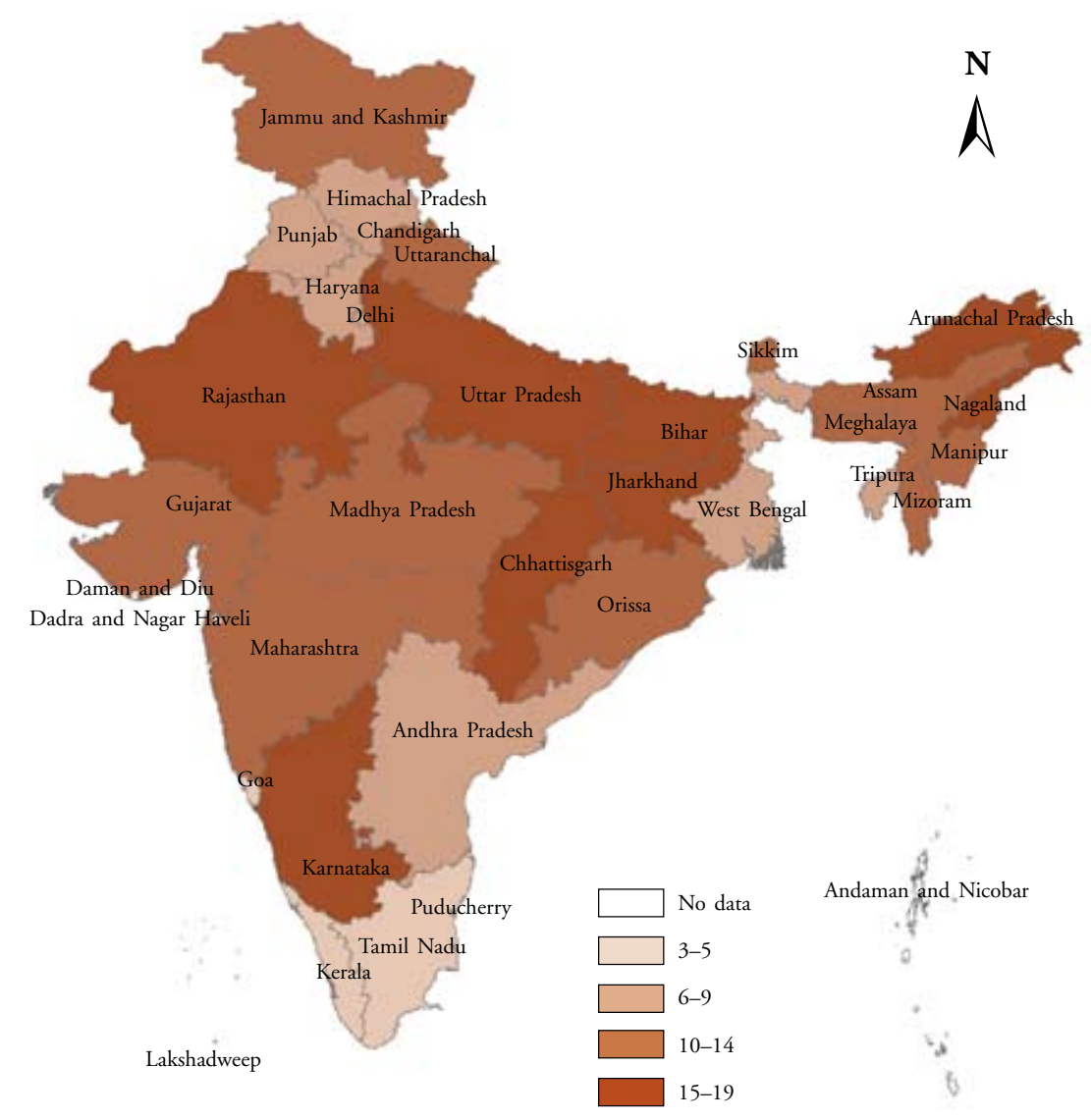

Source: Calculated from individual female respondent data from the NFHS-3.

pregnancy is indeed reported among significant minorities of sexually experienced unmarried youth. For example, the Youth Study reports that among young men and young women who had engaged in pre-marital sex with a romantic partner, four percent of young men and nine percent of young women reported a pregnancy (calculated from the Youth in India: Situation and Needs 2006-07 study). In a study among college students in Gujarat, 17 percent of sexually experienced males reported that they had made a girl pregnant and eight percent of sexually experienced females reported that they had experienced a pregnancy (Sujay, 2009).

\section{Unplanned pregnancy and abortion}

Unwanted fertility is experienced by considerable proportions of young women. As many as 17 percent of births to married young women aged 15-24 in the five years preceding the NFHS-3 were unplanned, that is, wanted at a later time or not wanted at all (International Institute for Population Sciences and Macro International, 2007). Births to young mothers (15-24) in the five years preceding the NFHS-3 that were unplanned ranged from nine percent in Delhi to 49 percent in Mizoram. Indeed, one-quarter or more of births (26-49\%) were 
Table 2.6

Percentage of women aged 20-24 who had given birth before age 18 and married women aged 15-24 with three or more children by background characteristics, India, 2005-06

\begin{tabular}{|c|c|c|}
\hline Background characteristics & $\begin{array}{l}\text { Given birth before age } 18 \\
20-24 \text { years }\end{array}$ & $\begin{array}{l}\text { Having three or more children } \\
15-24 \text { years }\end{array}$ \\
\hline \multicolumn{3}{|l|}{ Age (years) } \\
\hline $15-19$ & - & 1.4 \\
\hline $20-24$ & 21.7 & 17.5 \\
\hline \multicolumn{3}{|l|}{ Residence } \\
\hline Urban & 12.3 & 9.2 \\
\hline Rural & 26.3 & 14.1 \\
\hline \multicolumn{3}{|l|}{ Education } \\
\hline No education & 39.3 & 20.6 \\
\hline$<5$ years complete & 32.4 & 14.6 \\
\hline 5-7 years complete & 24.4 & 9.9 \\
\hline 8-9 years complete & 14.0 & 6.5 \\
\hline 10-11 years complete & 7.8 & 4.8 \\
\hline 12 or more years complete & 1.4 & 1.7 \\
\hline \multicolumn{3}{|l|}{ Religion } \\
\hline Hindu & 21.8 & 12.5 \\
\hline Muslim & 24.6 & 15.9 \\
\hline Other & 12.9 & 12.2 \\
\hline \multicolumn{3}{|l|}{ Caste/tribe } \\
\hline Scheduled caste & 26.6 & 14.5 \\
\hline Scheduled tribe & 30.6 & 16.0 \\
\hline Other backward caste & 22.8 & 13.7 \\
\hline General & 14.3 & 9.3 \\
\hline \multicolumn{3}{|l|}{ Wealth index } \\
\hline Poorest & 38.9 & 18.6 \\
\hline Poorer & 33.0 & 15.9 \\
\hline Middle & 23.3 & 12.0 \\
\hline Wealthier & 14.5 & 9.6 \\
\hline Wealthiest & 5.4 & 4.4 \\
\hline Total & 22.0 & 13.0 \\
\hline
\end{tabular}

Source: Calculated from individual female respondent data from the NFHS-3. 
Figure 2.6: Percentage of unplanned births to married young women aged 15-24 in the five years preceding the NFHS-3, according to state, India, 2005-06

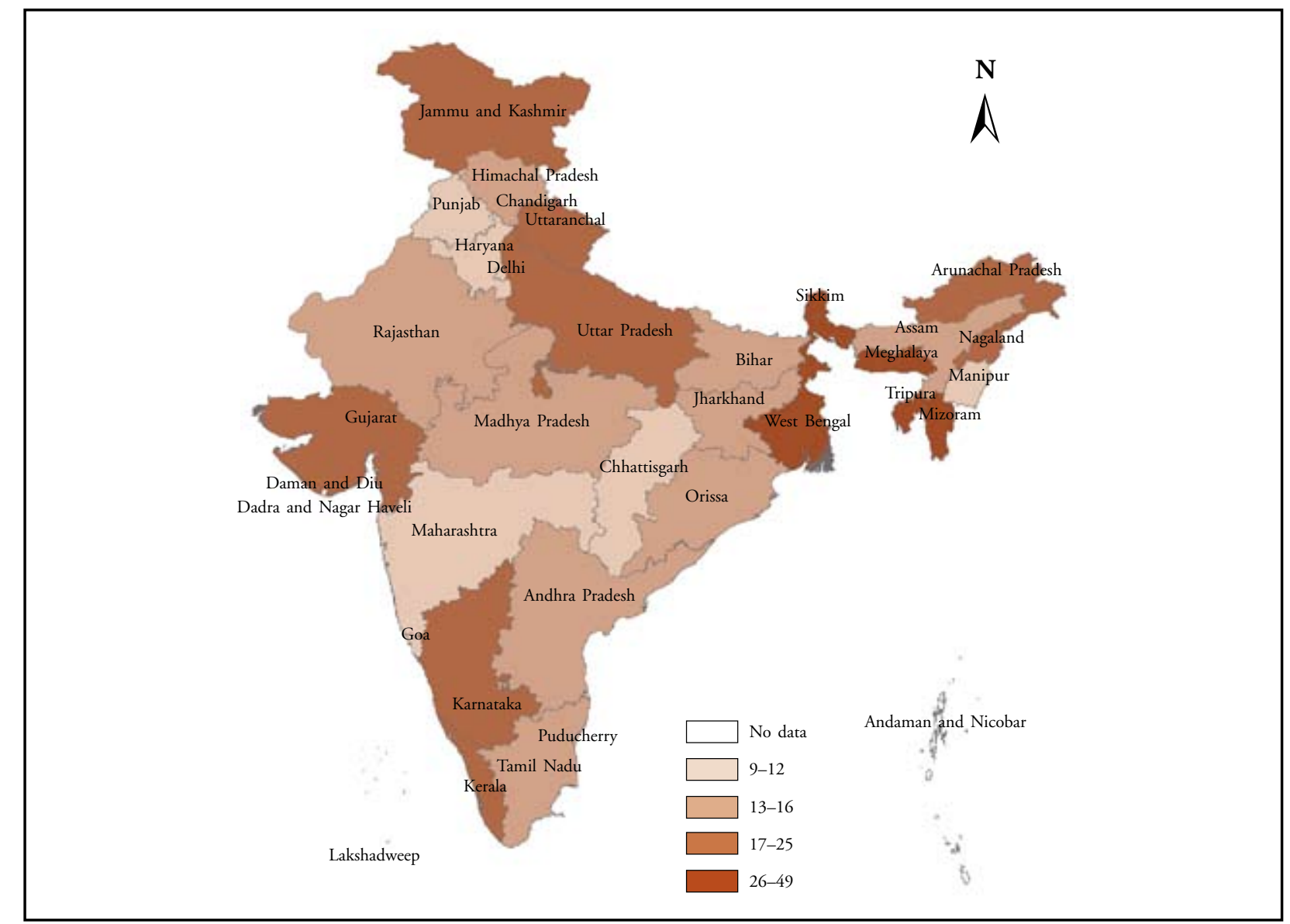

Source: Calculated from individual female respondent data from the NFHS-3.

unplanned in states such as Meghalaya, Mizoram, Sikkim, Tripura and West Bengal (Figure 2.6). Sociodemographic differentials, however, were modest (Table 2.7).

While not much is known about abortion among the young, evidence suggests that young women-irrespective of marital status-are more disadvantaged than adult women, and that unmarried young women are particularly disadvantaged. It is estimated that between one and 10 percent of abortion-seekers in India are adolescents (Ganatra, 2000), though a few facility-based studies report that the proportion of adolescent abortion-seekers is as high as one in three (Chhabra et al., 1988; Solapurkar and Sangam, 1985). A community-based study in rural Maharashtra reports that young women aged 15-24 constituted over one-half of married abortion-seekers who participated in the study (Ganatra and Hirve, 2002). In the study among college students in Gujarat referred to earlier, most pregnancies were aborted (Sujay, 2009). Evidence also suggests that young women who seek abortion often tend to delay seeking it into the second trimester; for example, 25 percent of unmarried and nine percent of married abortion-seekers had delayed seeking abortion into the second trimester (Jejeebhoy et al., 2010). 
Table 2.7

Percentage of unplanned births to married young women aged 15-24 in the five years preceding the NFHS-3 by background characteristics, India, 2005-06

\begin{tabular}{|c|c|}
\hline Background characteristics & $\begin{array}{l}\text { Women } \\
\text { 15-24 years }\end{array}$ \\
\hline \multicolumn{2}{|l|}{ Age (years) } \\
\hline $15-19$ & 14.4 \\
\hline $20-24$ & 18.1 \\
\hline \multicolumn{2}{|l|}{ Residence } \\
\hline Urban & 17.4 \\
\hline Rural & 16.7 \\
\hline \multicolumn{2}{|l|}{ Education } \\
\hline No education & 15.1 \\
\hline$<5$ years complete & 18.3 \\
\hline 5-7 years complete & 17.4 \\
\hline $8-9$ years complete & 19.6 \\
\hline 10-11 years complete & 19.2 \\
\hline 12 or more years complete & 16.8 \\
\hline \multicolumn{2}{|l|}{ Religion } \\
\hline Hindu & 16.2 \\
\hline Muslim & 20.5 \\
\hline Other & 14.8 \\
\hline \multicolumn{2}{|l|}{ Caste/tribe } \\
\hline Scheduled caste & 16.9 \\
\hline Scheduled tribe & 13.5 \\
\hline Other backward caste & 16.0 \\
\hline General & 18.7 \\
\hline \multicolumn{2}{|l|}{ Wealth index } \\
\hline Poorest & 14.8 \\
\hline Poorer & 17.9 \\
\hline Middle & 17.9 \\
\hline Wealthier & 17.5 \\
\hline Wealthiest & 15.9 \\
\hline Total & 17.0 \\
\hline
\end{tabular}

Source: Calculated from individual female respondent data from the NFHS-3. 
Table 2.8

Percentage of youth who were moderately or severely anaemic, according to state, India, $2005-06$

\begin{tabular}{|c|c|c|}
\hline State & $\begin{array}{c}\text { Men } \\
\text { 15-24 years }\end{array}$ & $\begin{array}{c}\text { Women } \\
\text { 15-24 years }\end{array}$ \\
\hline India & 11.1 & 17.4 \\
\hline North & 10.4 & 16.7 \\
\hline Delhi & 8.1 & 10.6 \\
\hline Haryana & 6.0 & 19.1 \\
\hline Himachal Pradesh & 9.8 & 10.7 \\
\hline Jammu \& Kashmir & 9.1 & 15.4 \\
\hline Punjab & 8.4 & 13.3 \\
\hline Rajasthan & 13.6 & 19.3 \\
\hline Uttaranchal & 13.8 & 15.7 \\
\hline Central & 11.9 & 15.7 \\
\hline Chhattisgarh & 11.3 & 19.1 \\
\hline Madhya Pradesh & 11.7 & 16.6 \\
\hline Uttar Pradesh & 12.0 & 14.9 \\
\hline East & 13.7 & 17.9 \\
\hline Bihar & 10.7 & 17.7 \\
\hline Jharkhand & 18.5 & 20.0 \\
\hline Orissa & 13.4 & 15.5 \\
\hline West Bengal & 14.8 & 18.4 \\
\hline Northeast & 15.7 & 20.1 \\
\hline Arunachal Pradesh & 13.6 & 14.3 \\
\hline Assam & 16.2 & 23.2 \\
\hline Manipur & 2.7 & 4.6 \\
\hline Meghalaya & 23.4 & 14.8 \\
\hline Mizoram & 10.8 & 9.9 \\
\hline Sikkim & 16.3 & 19.1 \\
\hline Tripura & 15.2 & 15.6 \\
\hline West & 8.6 & 17.7 \\
\hline Goa & 4.6 & 9.7 \\
\hline Gujarat & 10.3 & 20.3 \\
\hline Maharashtra & 7.7 & 16.4 \\
\hline South & 9.0 & 19.0 \\
\hline Andhra Pradesh & 11.0 & 25.6 \\
\hline Karnataka & 9.5 & 18.2 \\
\hline Kerala & 3.6 & 8.3 \\
\hline Tamil Nadu & 8.2 & 15.4 \\
\hline
\end{tabular}

Source: Calculated from individual male and female respondent data from the NFHS-3.

Note: Data are not available for Nagaland. 
Table 2.9

Percentage of youth who were moderately or severely anaemic by background characteristics, India, 2005-06

\begin{tabular}{|c|c|c|}
\hline Background characteristics & $\begin{array}{c}\text { Men } \\
\text { 15-24 years }\end{array}$ & $\begin{array}{l}\text { Women } \\
\text { 15-24 years }\end{array}$ \\
\hline \multicolumn{3}{|l|}{ Age (years) } \\
\hline $15-19$ & 13.5 & 16.6 \\
\hline $20-24$ & 8.4 & 18.4 \\
\hline \multicolumn{3}{|l|}{ Residence } \\
\hline Urban & 7.7 & 16.2 \\
\hline Rural & 13.0 & 18.1 \\
\hline \multicolumn{3}{|l|}{ Education } \\
\hline No education & 16.4 & 22.2 \\
\hline$<5$ years complete & 15.6 & 20.6 \\
\hline 5-7 years complete & 15.0 & 18.0 \\
\hline 8-9 years complete & 10.9 & 15.7 \\
\hline $10-11$ years complete & 8.8 & 14.9 \\
\hline 12 or more years complete & 5.3 & 11.8 \\
\hline \multicolumn{3}{|l|}{ Religion } \\
\hline Hindu & 11.3 & 17.7 \\
\hline Muslim & 9.9 & 16.6 \\
\hline Other & 10.5 & 17.2 \\
\hline \multicolumn{3}{|l|}{ Caste/tribe } \\
\hline Scheduled caste & 12.3 & 20.7 \\
\hline Scheduled tribe & 18.3 & 24.3 \\
\hline Other backward caste & 10.2 & 16.7 \\
\hline General & 9.5 & 14.5 \\
\hline \multicolumn{3}{|l|}{ Wealth index } \\
\hline Poorest & 17.6 & 21.5 \\
\hline Poorer & 14.2 & 19.4 \\
\hline Middle & 12.0 & 18.4 \\
\hline Wealthier & 8.7 & 16.0 \\
\hline Wealthiest & 6.0 & 12.8 \\
\hline Total & 11.0 & 17.0 \\
\hline
\end{tabular}

Source: Calculated from individual male and female respondent data from the NFHS-3. 


\section{RTIs/STIs and HIV}

The Youth Study also reports that significant proportions of youth had experienced symptoms of genital infection: five percent and 17 percent of young men and women, respectively, reported symptoms of genital infection in the three months preceding the interview, with married young women more likely than unmarried young women to report so (20\% versus $13 \%)$ (International Institute for Population Sciences and Population Council, 2010). Moreover, NFHS data suggest that young women were as likely as adult women to report STIs or symptoms of STIs (International Institute for Population Sciences and Macro International, 2007). Data on HIV prevalence (11\% and $9-12 \%$, respectively) indicate that age-specific HIV prevalence rates are similar among young men and young women aged 15-24 (0.09 and 0.11 respectively) (Parasuraman et al., 2009).

\section{Malnutrition}

Malnutrition characterises the life of many youth, particularly young women; as shown in Table 2.8, 11 percent and 17 percent of young men and women, respectively, were moderately or severely anaemic (see also Parasuraman et al., 2009). State-wise differentials were modest. Even so, the prevalence of moderate or severe anaemia among young men ranged from five percent or less in Goa, Kerala and Manipur to 15 percent or more in Assam, Jharkhand, Meghalaya, Sikkim, Tripura and West Bengal. Among young women, it ranged from 10 percent or less in Goa, Kerala, Manipur and Mizoram to 20 percent or more in Andhra Pradesh, Assam, Gujarat and Jharkhand.

Findings of differentials in malnutrition by background characteristics, presented in Table 2.9, also show that adolescent girls and young women were equally likely to be anaemic, though adolescent boys were much more likely to be anaemic than young men. Differences by education and wealth status are notable; for example, among young women, 22 percent of those with no education compared to 15 percent of those who had at least completed high school, and 22 percent of those belonging to the poorest households compared to 13 percent of those belonging to the richest households, were moderately or severely anaemic. 


\section{CHAPTER 3}

\section{Challenges in meeting youth sexual and reproductive health needs and rights}

A host of factors-operating at the individual, family and system levels_-inhibits young people from achieving good sexual and reproductive health and realising their rights.

\section{Individual-level barriers}

As described below, awareness of health-promoting behaviours, care-seeking for sexual and reproductive matters and social support remain limited among young people. Moreover, gender double standards and power imbalances shape young people's lives. All these tend to compromise young people's sexual and reproductive health.

\section{Limited awareness of health-promoting behaviours}

Notwithstanding the commitments articulated in several national policies and programmes to raise young people's awareness of sexual and reproductive matters, the reality is that most young men and women continue to lack awareness. As Table 3.1 shows, fewer than half of young men and women were aware that a woman can become pregnant at first sex or is most likely to conceive midway through her cycle $(37-45 \%$ and $38-39 \%$, respectively). Likewise, although the large majority of young people had heard of contraception and HIV/AIDS, few had in-depth awareness about contraceptive methods or modes of HIV transmission. For example, 76 percent of young men and 30 percent of young women knew that one male condom can be used for just one sexual intercourse. Similarly, 45 percent of young men and 28 percent of young women had displayed comprehensive awareness of HIV/AIDS. Fewer than one in five had even heard of sexually transmitted infections other than HIV/AIDS. Similarly, despite laws on the minimum age at marriage and legal abortion, awareness of legal minimum age at marriage for females was far from universal among young men and women (58-72\%), and just onequarter were aware that women are legally entitled to undergo abortion in India.

Socio-demographic differences in awareness of sexual and reproductive matters were notable. In Table 3.2, we present the percentage of youth who reported comprehensive awareness of HIV/AIDS by background characteristics to highlight this point. Comprehensive awareness of HIV/AIDS was greater among young men than young women $(45 \%$ versus $28 \%)$, unmarried youth than the married ( $47 \%$ versus 33\% among young men and $42 \%$ versus $24 \%$ among young women) and urban youth than the rural $59 \%$ versus $40 \%$ among young men and $33 \%$ versus $24 \%$ among young women). It was also greater among better educated (71\% of young men with 12 or more years of education compared to $13 \%$ of those with no education, for example), economically better off ( $49 \%$ of young women from the wealthiest quintile compared to $9 \%$ of those from the poorest quintile, for example) and sociallyincluded $(34 \%$ of young men belonging to scheduled 


\section{Table 3.1}

Awareness of sexual and reproductive health matters among youth aged 15-24, six states, 2006-07

\begin{tabular}{|c|c|c|}
\hline & $\begin{array}{l}\text { Men } \\
\text { 15-24 years }\end{array}$ & $\begin{array}{l}\text { Women } \\
\text { 15-24 years }\end{array}$ \\
\hline \multicolumn{3}{|l|}{ Sex and pregnancy-related matters } \\
\hline$\%$ youth who were aware that a woman can get pregnant at first sex & 36.5 & 45.1 \\
\hline $\begin{array}{l}\text { \% youth who were aware that a woman is most likely to become pregnant } \\
\text { mid-cycle }\end{array}$ & 38.5 & 38.4 \\
\hline \multicolumn{3}{|l|}{ Contraception } \\
\hline$\%$ youth who had heard of at least one method of contraception & 94.6 & 94.6 \\
\hline \% youth who were aware that one male condom can be used just once & 76.4 & 30.4 \\
\hline $\begin{array}{l}\text { \% youth who were aware that the emergency contraceptive pill can be taken } \\
\text { up to } 72 \text { hours after sex }\end{array}$ & 4.2 & 3.4 \\
\hline \multicolumn{3}{|l|}{ Awareness of HIV and STIs } \\
\hline \% youth who had ever heard of HIV/AIDS & 90.7 & 72.5 \\
\hline$\%$ youth with comprehensive awareness of HIV/AIDS & 45.4 & 28.4 \\
\hline$\%$ youth who had heard of STIs & 19.0 & 14.9 \\
\hline \multicolumn{3}{|l|}{ Legal issues relating to $\mathrm{SRH}$} \\
\hline$\%$ youth who were aware of the legal minimum age at marriage for females & 71.7 & 58.1 \\
\hline$\%$ youth who were aware that abortion is legal & 25.7 & 22.9 \\
\hline
\end{tabular}

Source: International Institute for Population Sciences and Population Council, 2010.

tribes compared to $53 \%$ of those belonging to general castes, for example) youth than others.

\section{Limited health care seeking practices}

Although there are a host of policies and programmes that seek to improve young people's access to sexual and reproductive health services, many young people do not seek proper care for sexual and reproductive health problems. For example, as shown in Table 2.3, few sexuallyexperienced, unmarried youth had used condoms consistently in pre-marital relationships (13\% of young men and 3\% of young women). Contraceptive use, likewise, was limited within marriage. Not surprisingly, the unmet need for contraception was higher among married young women than adult women (23\% compared to $11 \%$ among those aged 30-34; International Institute for Population Sciences and Macro International, 2007). As illustrated in Figure 3.1, unmet need among married young women ranged from 15 percent or less in Adhra Pradesh, Assam, Haryana, Manipur, Punjab and West Bengal to 30 percent or more in Bihar, Jharkhand, Meghalaya, Mizoram, Nagaland, Sikkim and Uttar Pradesh (Parasuraman et al., 2009). Socio-demographic differences were mild except that married adolescent girls were slightly more likely than their 20-24 year-old counterparts to report unmet need (27\% versus $21 \%$ ) (Table 3.3 ).

As mentioned earlier, access to abortion services is considerably more limited among young women than adult women, and is particularly poor among 
Table 3.2

Percentage of youth who had comprehensive awareness of HIV/AIDS by background characteristics, six states, 2006-2007

\begin{tabular}{|c|c|c|}
\hline Background characteristics & $\begin{array}{c}\text { Men } \\
15-24 \text { years }\end{array}$ & $\begin{array}{l}\text { Women } \\
\text { 15-24 years }\end{array}$ \\
\hline \multicolumn{3}{|l|}{ Age (years) } \\
\hline $15-19$ & 42.3 & 25.1 \\
\hline $20-24$ & 48.9 & 32.0 \\
\hline \multicolumn{3}{|l|}{ Residence } \\
\hline Urban & 58.7 & 43.0 \\
\hline Rural & 39.6 & 22.3 \\
\hline \multicolumn{3}{|l|}{ Marital status } \\
\hline Unmarried & 47.1 & 33.3 \\
\hline Married & 41.8 & 23.9 \\
\hline \multicolumn{3}{|l|}{ Education } \\
\hline No education & 13.2 & 4.7 \\
\hline$<5$ years complete & 18.7 & 10.6 \\
\hline 5-7 years complete & 28.7 & 21.1 \\
\hline 8-9 years complete & 43.2 & 32.8 \\
\hline 10-11 years complete & 57.7 & 46.2 \\
\hline 12 or more years complete & 71.0 & 62.2 \\
\hline \multicolumn{3}{|l|}{ Religion } \\
\hline Hindu & 45.3 & 28.6 \\
\hline Muslim & 43.8 & 22.9 \\
\hline Other & 50.1 & 33.5 \\
\hline \multicolumn{3}{|l|}{ Caste/tribe } \\
\hline Scheduled caste & 43.0 & 26.2 \\
\hline Scheduled tribe & 34.0 & 17.9 \\
\hline Other backward caste & 45.0 & 27.4 \\
\hline General caste & 53.3 & 36.8 \\
\hline \multicolumn{3}{|l|}{ Wealth index } \\
\hline Poorest & 20.7 & 8.8 \\
\hline Poorer & 31.0 & 16.5 \\
\hline Middle & 43.5 & 26.2 \\
\hline Wealthier & 51.5 & 35.0 \\
\hline Wealthiest & 65.4 & 48.5 \\
\hline Total & 45.0 & 28.0 \\
\hline
\end{tabular}

Source: International Institute for Population Sciences and Population Council, 2010. 
Figure 3.1: Percentage of married young women with an unmet need for contraceptives, according to state, India, 2005-06

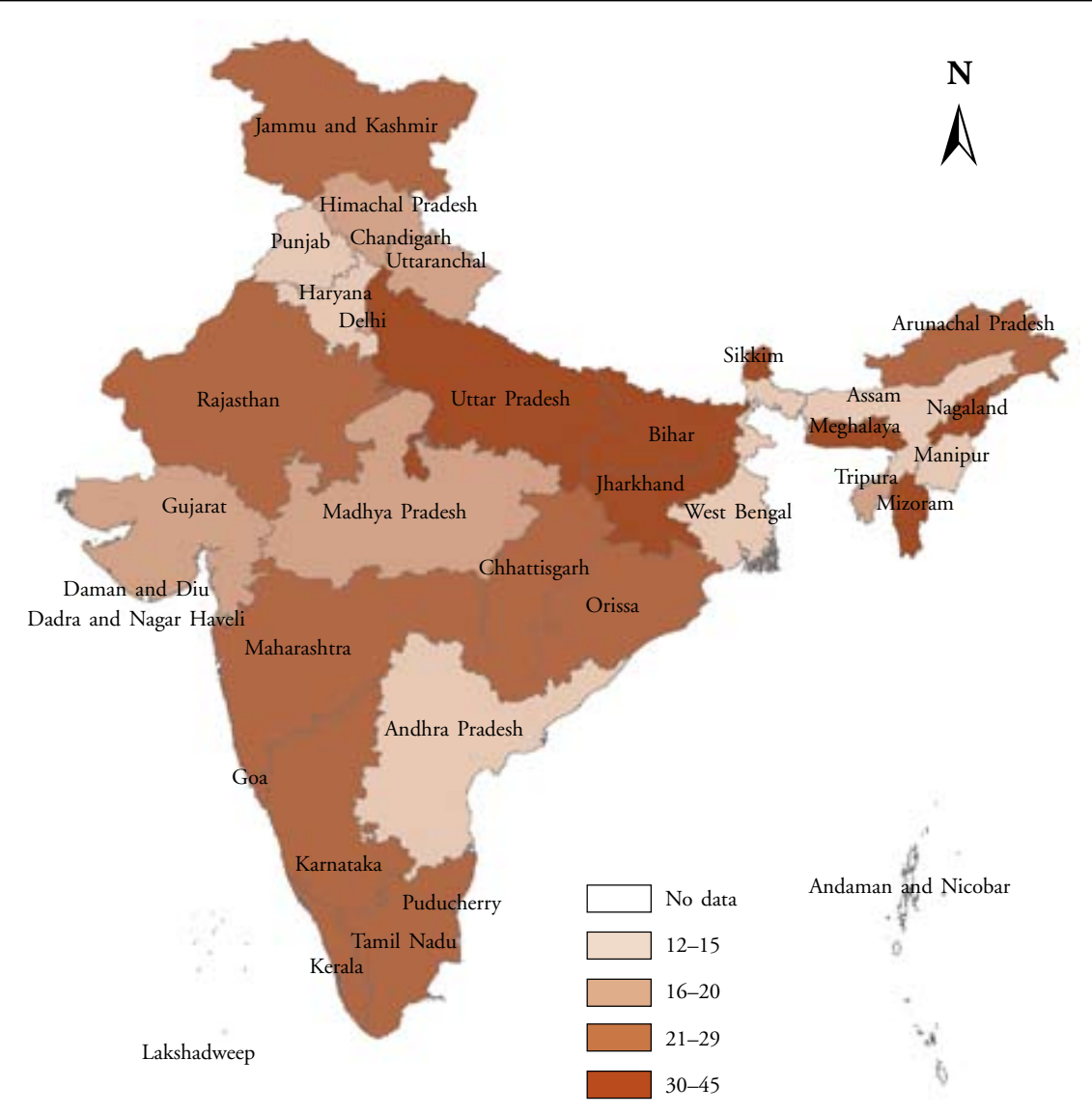

Source: Calculated from individual female respondent data from the NFHS-3.

the unmarried. Adolescents were more likely than older women, and unmarried adolescents more likely than their married counterparts, to seek abortions from unqualified or untrained providers, to have delayed abortions, and to have undergone second trimester abortions (Ganatra and Hirve, 2002; Jejeebhoy et al., 2010).

Accessing pregnancy-related services is also limited among young women despite the fact that many of them are experiencing their first and most risky pregnancy at a young age. Just 54 percent of young women had received three or more antenatal check-ups, 40 percent of young women reported an institutional delivery and 37 percent of young women had received a postpartum check-up within two days of delivery. Notable state-wise differences in utilisation of maternal health services persist. Less than one in three married young women had received three or more antenatal check-ups during their pregnancy in the five years preceding the NFHS-3 in Bihar and Uttar Pradesh; in contrast, more than nine in ten had received these services in Kerala and Tamil Nadu (Table 3.4). Likewise, in Assam, Bihar, Chhattisgarh, Jharkhand, Nagaland and Uttar Pradesh, less than one in four births 


\section{Table 3.3}

Percentage of married young women with an unmet need for contraceptives by background characteristics, India, 2005-06

\begin{tabular}{|c|c|}
\hline Background characteristics & $\begin{array}{l}\text { Women } \\
\text { 15-24 years }\end{array}$ \\
\hline \multicolumn{2}{|l|}{ Age (years) } \\
\hline $15-19$ & 27.1 \\
\hline $20-24$ & 21.1 \\
\hline \multicolumn{2}{|l|}{ Residence } \\
\hline Urban & 20.9 \\
\hline Rural & 23.4 \\
\hline \multicolumn{2}{|l|}{ Education } \\
\hline No education & 22.7 \\
\hline$<5$ years complete & 20.8 \\
\hline 5-7 years complete & 23.8 \\
\hline $8-9$ years complete & 23.2 \\
\hline 10-11 years complete & 23.2 \\
\hline 12 or more years complete & 21.8 \\
\hline \multicolumn{2}{|l|}{ Religion } \\
\hline Hindu & 22.4 \\
\hline Muslim & 26.0 \\
\hline Other & 19.9 \\
\hline \multicolumn{2}{|l|}{ Caste/tribe } \\
\hline Scheduled caste & 21.5 \\
\hline Scheduled tribe & 19.9 \\
\hline Other backward caste & 24.8 \\
\hline General & 22.3 \\
\hline \multicolumn{2}{|l|}{ Wealth index } \\
\hline Poorest & 24.1 \\
\hline Poorer & 23.1 \\
\hline Middle & 23.2 \\
\hline Wealthier & 22.8 \\
\hline Wealthiest & 19.6 \\
\hline Total & 23.0 \\
\hline
\end{tabular}

Source: Calculated from individual female respondent data from the NFHS-3. 
Table 3.4

Among infants born to young women in the five years preceding the NFHS-3, percentage whose mother received maternal health services, according to state, India, 2005-06

\begin{tabular}{|c|c|c|c|}
\hline State & $\begin{array}{c}\text { Three or more antenatal } \\
\text { check-ups }\end{array}$ & $\begin{array}{l}\text { Institutional } \\
\text { delivery }\end{array}$ & $\begin{array}{l}\text { Postpartum check-up } \\
\text { within two days }\end{array}$ \\
\hline India & 54.1 & 40.1 & 37.3 \\
\hline North & 55.2 & 39.7 & 42.1 \\
\hline Delhi & 68.9 & 48.3 & 46.7 \\
\hline Haryana & 62.5 & 41.2 & 58.9 \\
\hline Himachal Pradesh & 58.7 & 39.4 & 36.8 \\
\hline Jammu \& Kashmir & 74.9 & 49.3 & 47.7 \\
\hline Punjab & 74.5 & 48.8 & 61.4 \\
\hline Rajasthan & 44.4 & 35.5 & 31.7 \\
\hline Uttaranchal & 42.2 & 30.4 & 24.5 \\
\hline Central & 33.5 & 22.0 & 18.3 \\
\hline Chhattisgarh & 54.8 & 13.1 & 24.3 \\
\hline Madhya Pradesh & 40.5 & 27.8 & 30.4 \\
\hline Uttar Pradesh & 28.4 & 21.1 & 13.3 \\
\hline East & 44.1 & 30.9 & 26.9 \\
\hline Bihar & 20.8 & 22.2 & 14.8 \\
\hline Jharkhand & 39.5 & 20.0 & 16.9 \\
\hline Orissa & 65.0 & 38.3 & 33.9 \\
\hline West Bengal & 63.5 & 42.8 & 41.0 \\
\hline Northeast & 45.5 & 26.0 & 17.4 \\
\hline Arunachal Pradesh & 43.7 & 33.3 & 27.3 \\
\hline Assam & 41.4 & 20.7 & 12.0 \\
\hline Manipur & 70.8 & 43.5 & 43.7 \\
\hline Meghalaya & 52.0 & 30.9 & 26.6 \\
\hline Mizoram & 54.8 & 58.3 & 47.6 \\
\hline Nagaland & 38.7 & 15.4 & 13.9 \\
\hline Sikkim & 67.5 & 47.8 & 42.6 \\
\hline Tripura & 60.3 & 46.6 & 31.5 \\
\hline West & 70.6 & 59.9 & 56.2 \\
\hline Goa & 88.6 & 79.6 & 74.2 \\
\hline Gujarat & 64.8 & 53.0 & 55.9 \\
\hline Maharashtra & 73.2 & 63.1 & 56.3 \\
\hline South & 87.1 & 70.8 & 67.1 \\
\hline Andhra Pradesh & 88.0 & 65.7 & 64.8 \\
\hline Karnataka & 78.2 & 61.2 & 54.0 \\
\hline Kerala & 93.3 & 98.8 & 81.3 \\
\hline Tamil Nadu & 97.4 & 90.3 & 88.0 \\
\hline
\end{tabular}

Source: Calculated from individual female respondent data from the NFHS-3. 
to married young women in the last five years had taken place in a health facility, compared to 90 percent or more in Kerala and Tamil Nadu. State-wise differences in postpartum care show that one-quarter or fewer women had received a postpartum check-up within two days of delivery in Assam, Bihar, Chhattisgarh, Jharkhand, Nagaland, Uttaranchal and Uttar Pradesh; in comparison, three-quarters or more of women in Goa, Kerala and Tamil Nadu had received such a check-up.

Socio-demographic differentials in maternal health services received by young women in the five years preceding the NFHS-3, presented in Table 3.5, indicate that rural, less educated and poor young women were less likely than others to have received three or more antenatal checkups, delivered in a health facility and received a postpartum check-up within two days of delivery. For example, 32 percent, 17 percent and 17 percent of young women from the poorest quintile had received three or more check-ups, delivered in a health facility and received a postpartum checkup within two days of delivery, respectively; the corresponding percentages among those from the wealthiest quintile were 83 percent, 79 percent and 70 percent, respectively. Differences by caste status were also evident: the socially excluded, particularly, those belonging to scheduled tribes, were less likely than others to receive these services $(42-50 \%$ compared to $53-65 \%$ with respect to three or more antenatal check-ups, for example).

For symptoms of genital infection too, there is evidence that care-seeking is limited; just 56 percent of young men and 40 percent of young women who experienced symptoms of infection in the three months preceding the survey had sought care for such symptoms (International Institute for Population Sciences and Population Council, 2010). The National Behavioural Surveillance Survey reports that 55 percent of young men and 43 percent of young women had sought care from a government or private health facility for symptoms of STIs experienced in the one year preceding the survey (National Institute of Medical Statistics and National AIDS Control Organisation, 2008). Limited care-seeking for symptoms of gynaecological morbidity has also been observed in other studies (Andrew and Patel, 2002; Barua and Kurz, 2001; Prasad et al., 2005; Rani and Bonu, 2003). Just four percent and 11 percent of young men and women had ever undergone an HIV test (International Institute for Population Sciences and Population Council, 2010).

Also evident of young people's limited access to sexual and reproductive health services are findings from the Youth Study that a large proportion of youth-two-fifths of young men and half of young women-felt uncomfortable to approach health care providers for sexual and reproductive health services, including contraceptive supplies, as seen in Figure 3.2 (International Institute for Population

Figure 3.2: Percentage of youth reporting discomfort about accessing SRH services from health care providers, six states, 2006-07

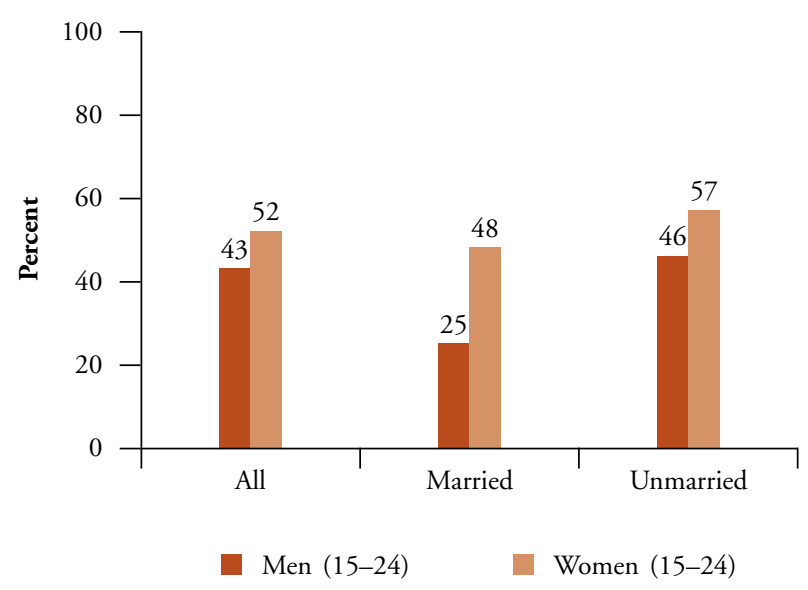

Source: International Institute for Population Sciences and Population Council, 2010. 
Sciences and Population Council, 2010). Notably, married young women were just marginally less likely to express such discomfort than the unmarried, and even among young men, as many as one-quarter of the married expressed discomfort. Indeed, further analyses of these data suggest that among youth who had engaged in pre-marital sex, those who did not report discomfort in accessing services from a provider were twice as likely as those who did to have used condoms (Santhya, Acharya and Jejeebhoy, 2011). Similarly, among married young women with symptoms suggestive of RTIs, those who did not report discomfort in accessing services from a provider were 1.3 times more likely than those who did to have sought treatment for such symptoms from formal providers (Sabarwal and Santhya, 2011).

\section{Gender power imbalances and limited female agency}

Gender double standards and power imbalances shape young people's life and often undermine their ability—and notably, young women's ability—to make sexual and reproductive choices both in marital and pre-marital partnerships. The Youth Study, for example, reports that just 27 percent of young women (compared to $56 \%$ of young men) made decisions independently on personal matters. Young women's mobility was also restricted: 73 percent were permitted to visit a place in their own village unescorted (compared to almost all unmarried young men), and 24 percent were permitted to visit a place outside their own village unescorted (compared to $82 \%$ of unmarried young men). Finally, young women's control over money was similarly more restricted than that of young men's $54 \%$ of young women versus $90 \%$ of young men who owned a bank account controlled its operation) (International Institute for Population Sciences and Population Council, 2010).
Young women's agency varied considerably by socio-demographic characteristics as evident from Table 3.6. Specifically, decision-making autonomy was greater among young women aged 20-24 than those aged $15-19$ (31\% versus $23 \%$ ), those residing in urban than rural settings ( $35 \%$ versus $24 \%$ ), and those belonging to general castes compared to those belonging to scheduled castes, scheduled tribes and other backward castes (36\% versus 24-26\%). It was also greater among young women who were more educated and belonged to wealthier households than their respective counterparts (48\% of young women with 12 or more years of education compared to $18 \%$ of those with no education, and $40 \%$ of those from the wealthiest quintile compared to $20 \%$ of those from the poorest quintile). Freedom of movement, similarly, increased with age, education and household economic status; additionally, urban women were more likely than their rural counterparts to report freedom of movement. Finally, similar differences were evident with regard to having some savings as well.

In the sexual and reproductive health arena, limited agency is evident from young women's lack of voice in decisions on when and whom to marry and on engaging in safe sex. The Youth Study reports that one-quarter of married young women (compared to $11 \%$ of married young men) played no role in determining the timing of their marriage or the selection of their spouse (International Institute for Population Sciences and Population Council, 2010). Moreover, among those who had engaged in pre-marital sex, while about two in five young men and women reported that the decision to use contraception was made jointly, one-half reported that the decision was made by the male partner on his own (46-54\%). Also indicative of young women's limited agency is their experience of violence within marriage. A multivariate analysis of the correlates of 
Table 3.5

Among infants born to young women in the five years preceding the NFHS-3, percentage whose mother received maternal health services by background characteristics, India, 2005-06

\begin{tabular}{|c|c|c|c|}
\hline Background characteristics & $\begin{array}{l}\text { Three or more } \\
\text { antenatal check-ups }\end{array}$ & $\begin{array}{l}\text { Institutional } \\
\text { delivery }\end{array}$ & $\begin{array}{l}\text { Postpartum check-up } \\
\text { within two days }\end{array}$ \\
\hline \multicolumn{4}{|l|}{ Age (years) } \\
\hline $15-19$ & 53.0 & 37.9 & 34.9 \\
\hline $20-24$ & 54.8 & 42.3 & 39.0 \\
\hline \multicolumn{4}{|l|}{ Residence } \\
\hline Urban & 73.7 & 64.7 & 57.3 \\
\hline Rural & 48.0 & 32.9 & 31.1 \\
\hline \multicolumn{4}{|l|}{ Education } \\
\hline No education & 34.8 & 21.9 & 21.1 \\
\hline$<5$ years complete & 52.2 & 36.0 & 31.1 \\
\hline 5-7 years complete & 64.0 & 48.7 & 43.2 \\
\hline 8-9 years complete & 67.4 & 55.7 & 47.3 \\
\hline 10-11 years complete & 80.1 & 70.4 & 64.9 \\
\hline 12 or more years complete & 84.7 & 78.7 & 71.0 \\
\hline \multicolumn{4}{|l|}{ Religion } \\
\hline Hindu & 53.9 & 40.4 & 37.2 \\
\hline Muslim & 51.9 & 36.6 & 34.6 \\
\hline Other & 66.2 & 49.9 & 50.2 \\
\hline \multicolumn{4}{|l|}{ Caste/tribe } \\
\hline Scheduled caste & 49.6 & 37.0 & 34.0 \\
\hline Scheduled tribe & 42.2 & 21.5 & 26.0 \\
\hline Other backward caste & 52.5 & 39.8 & 36.0 \\
\hline General & 65.0 & 52.2 & 48.4 \\
\hline \multicolumn{4}{|l|}{ Wealth index } \\
\hline Poorest & 32.3 & 17.3 & 16.9 \\
\hline Poorer & 41.6 & 28.7 & 26.6 \\
\hline Middle & 58.7 & 42.1 & 38.2 \\
\hline Wealthier & 70.9 & 58.8 & 52.7 \\
\hline Wealthiest & 83.3 & 78.9 & 70.0 \\
\hline Total & 54.1 & 40.1 & 37.3 \\
\hline
\end{tabular}

Source: Calculated from individual female respondent data from the NFHS-3. 
Table 3.6

Percentage of young women reporting exercise of agency by background characteristics, six states, 2006-07

\begin{tabular}{|c|c|c|c|}
\hline Background characteristics & $\begin{array}{l}\text { Decision-making } \\
\text { autonomy }\end{array}$ & $\begin{array}{c}\text { Freedom to visit } \\
\text { village/neighbourhood } \\
\text { unescorted }\end{array}$ & Has savings \\
\hline \multicolumn{4}{|l|}{ Age (years) } \\
\hline $15-19$ & 23.1 & 19.0 & 34.3 \\
\hline $20-24$ & 31.0 & 28.8 & 38.8 \\
\hline \multicolumn{4}{|l|}{ Residence } \\
\hline Urban & 34.6 & 33.2 & 43.2 \\
\hline Rural & 23.6 & 19.7 & 33.6 \\
\hline \multicolumn{4}{|l|}{ Education } \\
\hline No education & 18.2 & 16.0 & 31.1 \\
\hline$<5$ years complete & 16.1 & 14.7 & 27.1 \\
\hline 5-7 years complete & 21.5 & 18.1 & 29.0 \\
\hline 8-9 years complete & 26.5 & 23.5 & 39.1 \\
\hline 10-11 years complete & 32.5 & 27.1 & 40.9 \\
\hline 12 or more years complete & 48.4 & 45.1 & 51.0 \\
\hline \multicolumn{4}{|l|}{ Religion } \\
\hline Hindu & 26.9 & 24.3 & 36.8 \\
\hline Muslim & 22.9 & 13.8 & 33.8 \\
\hline Other & 32.1 & 30.8 & 35.6 \\
\hline \multicolumn{4}{|l|}{ Caste/tribe } \\
\hline Scheduled caste & 23.6 & 23.5 & 34.3 \\
\hline Scheduled tribe & 25.9 & 25.2 & 32.2 \\
\hline Other backward caste & 24.6 & 20.8 & 35.5 \\
\hline General & 36.1 & 30.2 & 42.6 \\
\hline \multicolumn{4}{|l|}{ Wealth index } \\
\hline Poorest & 20.0 & 15.1 & 30.0 \\
\hline Poorer & 20.4 & 17.5 & 30.3 \\
\hline Middle & 23.1 & 21.7 & 32.3 \\
\hline Wealthier & 27.5 & 25.6 & 36.8 \\
\hline Wealthiest & 40.2 & 35.3 & 49.9 \\
\hline Total & 26.9 & 23.7 & 36.4 \\
\hline
\end{tabular}

Source: International Institute for Population Sciences and Population Council 2010. 
physical and sexual violence, using data from the Youth Study, shows that young women who made decisions on their own were significantly less likely than those who did not to have experienced each form of violence, and those who reported selfefficacy were considerably less likely than others to experience violence. The risk of experiencing physical and sexual violence was 20-25 percent lower among young women who reported self-efficacy than among those who did not so report (Acharya et al., 2009).

Young people themselves often accept—and sometimes justify-double standards that condone and even encourage pre-marital relations for men but not for women. Findings from the Youth Study suggest that while 64-69 percent of young men and women believed that a man's life would be ruined if he engaged in pre-marital sex, this percentage was considerably higher with regard to opinions about a woman's life (82-94\%; International Institute for Population Sciences and Population Council, 2010). Other gender role attitudes held by both young women and men-for example, that a woman must obtain her husband's permission for most things and that a man is justified in beating his wife on several matters-also have implications for women's ability to exercise choice in sexual and reproductive matters.

A different set of gender-related factors underlie the vulnerability of young men. While young men are not subject to the stringent behavioural constraints imposed on young women, emerging evidence from a small number of studies indicates that the social construction of masculinity may undermine young men's decision-making abilities as well as their involvement in care and support of their wives in sexual and reproductive health matters and their ability to adopt protective behaviours. Studies that have explored the role of young husbands in decisions related to the use of contraception, timing of first pregnancy or care during pregnancy report that such decisions were beyond the control of a substantial proportion of both young women and their husbands; for example, even where young women and their husbands would have liked to delay pregnancy, the decision to practise contraception was often overruled by senior family members (Barua and Kurz, 2001; Santhya et al., 2003). They also suggest that prevailing norms about masculinity may inhibit married young men from playing a supportive role in the sexual and reproductive health of their wives, including in pregnancy-related care. Moreover, young men, married and unmarried, are affected by social pressure to have sex at an early age, as well as a sense of entitlement to sex in and outside of marriage, often under risky conditions, thereby putting young men and their partners at risk of STIs/HIV (Jejeebhoy and Sebastian, 2004). Evidence from a study conducted in India, by the Population Council suggests clear linkages between inequitable gender attitudes and traditional masculinity norms on the one hand, and high-risk behaviours among men, including unprotected sex and gender-based violence, on the other (Verma et al., 2006).

\section{Lack of social support}

Youth, in general, gain support from their peer networks, both informal and formal. However, findings from the Youth Study show that social support networks are limited among young people, especially young women. For example, just 22 percent of young women, compared to 42 percent of young men reported at least five friends and just one-tenth reported membership in an organised group (International Institute for Population Sciences and Population Council, 2010). Analysis of the associations between peer-level factors and risky sex suggests that while young people reporting close peer connections were indeed more 
likely than others to report pre-marital sex (hazards ratios of 1.2-1.3; Santhya et al., 2011a); among the sexually experienced, those with close peer relations were significantly more likely than others to have used condoms. Qualitative data also indicate the influence of peers in informing youth about contraceptive methods and condom use, and among young men, even how to use condoms, where to get condoms, and help in procuring condoms (Santhya, Acharya and Jejeebhoy, 2011).

\section{Family-level barriers}

Young people, in general, lack a safe and supportive family environment, a shortcoming that is likely to pose major obstacles to their achievement of good sexual and reproductive health and the realisation of their rights. Parents often fail to serve as reliable sources of information for young people. A qualitative study with over 400 mothers and fathers of youth aged 15-24 in six states of India noted a number of factors that prevented parents from discussing sexual and reproductive matters with their children. For example, parents perceived that such discussion went against cultural norms and that youth today become aware of these matters on their own. Reasons cited by parents also included discomfort and embarrassment, both on the part of parents themselves and on the part of their children, about such discussion, and parental apprehensions that communicating about sexual matters would lead their children to engage in sexual activity (Jejeebhoy and Santhya, 2011). Narratives of parents from this study are reproduced below:

"No, all these things (discussing about physical relationship with children) don't work in our village. No, all this does not work in our society." [Mother, Jharkhand, rural, aged 39 years, no education]
"To talk (pause) with your sons and daughters is not possible. Parents will not talk like that because our culture is not that type." [Father, Maharashtra, rural, aged 55 years, graduate]

"No. How can I tell her such things? Parents cannot tell daughters about such sensitive matters. This is told to them by their girl friends. Parents feel shy to talk about such things. After all, I am her mother; she cannot talk (to me) about it." [Mother, Maharashtra, rural, aged 42 years, no education]

"I would not ask her anything about it (menstruation). I would feel bad (to ask).... Yes, I would feel very shy. When one's daughter grows up, one is bound to feel shy." [Mother, Bihar, rural, aged 45 years, no education] "But when I try to tell her, she tells me to keep quiet; that she knows everything. Girls feel shy to share with their parents; they can speak freely with their friends but they feel shy to speak to their mother." [Mother, Maharashtra, urban, aged 38 years, Educational attainment level not available] "She will become spoilt if I tell her such matters." [Mother, Andhra Pradesh, rural, aged 32 years, Class 7]

"No. They will become spoilt. They will go in the "galat" (wrong) line (path)." [Mother, Bihar, urban, aged 45 years, no education]

"He will be curious to know what will happen next. The chances of going on the wrong path are greater. Therefore, we don't discuss such topics." [Father, Maharashtra, urban, aged 44 years, Class 7]

Other studies have also identified parents' own lack of awareness, their perception that their children were not at risk of HIV, and parental discomfort and perceptions that informing their 
Figure 3.3: Percentage of youth reporting communication about sensitive matters with their mother or father, six states, 2006-07

Discussed with father

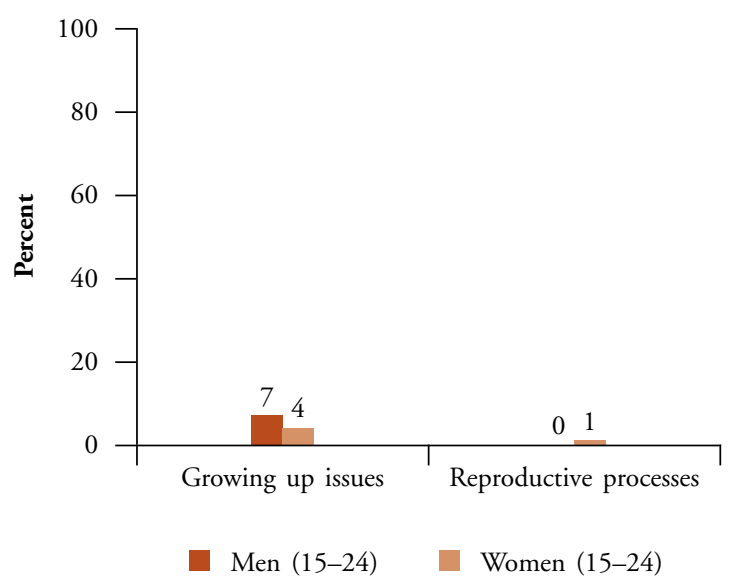

\section{Discussed with mother}

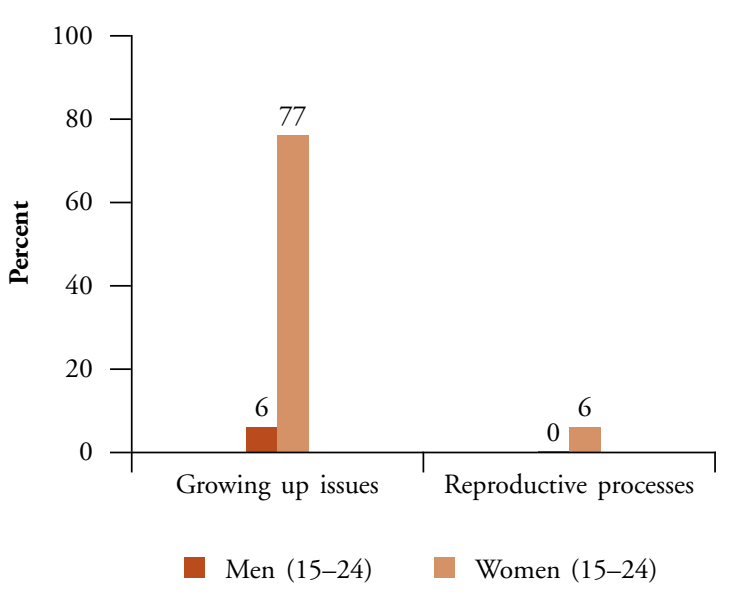

Source: International Institute for Population Sciences and Population Council, 2010.

children about sexual matters would lead youth to engage in sex as key factors limiting communication (Soletti et al., 2009; Mahajan and Sharma, 2005; Garda and Alexander, 2009; Shetty, Kowli and Patil, nd). Not surprisingly, the Youth Study reports that fewer than 10 percent of young men and women had discussed growing up or pregnancy and reproduction-related matters with either of their parents; the exception was the finding that 77 percent of young women had discussed growing up matters with their mother; this discussion was limited, however, to the mechanics of menstruation ("how to use the cloth") and behavioural dos and don'ts (Figure 3.3; International Institute for Population Sciences and Population Council, 2010).

Authoritarian childrearing practices and parental violence characterise the life of many young people. For example, findings from the Youth Study show that as many as one-quarter of young men and women had observed their father beating their mother. Many reported experiencing beating by a parent during adolescence 47 percent of young men and 19 percent of young women; (International Institute for Population Sciences and Population Council, 2010). Although only a few studies in India have explored the links between parental closeness and sexual and reproductive health outcomes among young people, they reiterate the importance of the former. A study of youth in Pune reports that closeness to parents was negatively associated with pre-marital romantic and sexual relationships among young women (Alexander et al., 2006). Findings from the Youth Study, likewise, underscore the role that a supportive family environment plays: youth who reported a parent as confidante were significantly less likely than others to initiate pre-marital sex early (hazards ratios of 0.782 and 0.875 for young women and men, respectively; Santhya et al., 2011a). In contrast, young women who had witnessed parental violence and experienced 
violence at the hands of parents were 1.3 times more likely than others to initiate pre-marital sex early. Moreover, young men who had witnessed parental violence and experienced violence at the hands of parents were more likely than others to perpetrate marital violence (Acharya et al., 2009).

\section{Systemic challenges}

Serious shortcomings at the systemic level have compromised young people's achievement of good sexual and reproductive health and realisation of their rights.

\section{Unmet need in educating the young}

As evident from the discussion earlier, sexual and reproductive health outcomes, regardless of the indicator, are poor and the realisation of related rights are limited among young people with no and limited education. These findings underscore the failure of the educational system to provide acceptable standards of schooling to young people. Just 42 percent of young men and 32 percent of young women aged 18-24 had completed Class 10 (International Institute for Population Sciences and Macro International, 2007). The government has articulated its commitment to improving the schooling situation in the country in several policies and acts, but there has not been a strong commitment to ensuring that these programmes are effectively implemented and that these do indeed reach the most disadvantaged groups. Efforts have failed to address the economic pressures that dissuade parents from enrolling their children in school and from keeping them in school once enrolled. Schoollevel barriers, notably, poor infrastructure, quality of education and academic failure, particularly among young women, have not been overcome, and efforts to incorporate livelihood skills building models within the school setting have not been established.
Uneven and poor implementation of programmes intended to raise awareness of sexual and reproductive matters

Although a large number of programmes have been implemented to raise young people's awareness of sexual and reproductive matters, implementation of these programmes has been marred by several concerns. For example, they have focused more on young people in schools and colleges than those outside the educational system. Moreover, the focus has been on students in Classes IX and XI; as a result, those who discontinue school prematurelygirls, the poor and the socially excluded-are not reached by school-based programmes. Moreover, despite international evidence of the need to initiate such education at an earlier age, younger adolescents are excluded from age-appropriate education. Outside of the school system, programmes imparted through the Nehru Yuvak Kendras and youth clubs, and even the media, likewise, are likely to reach more males than females, given the gendered nature of youth participation in government and communityled programmes, and in exposure to the mass media (see Jejeebhoy and Santhya, 2011 for a review of programmes).

Figure 3.4: Access to formal life skills/sex education among married and unmarried young men and women, six states, 2006-07

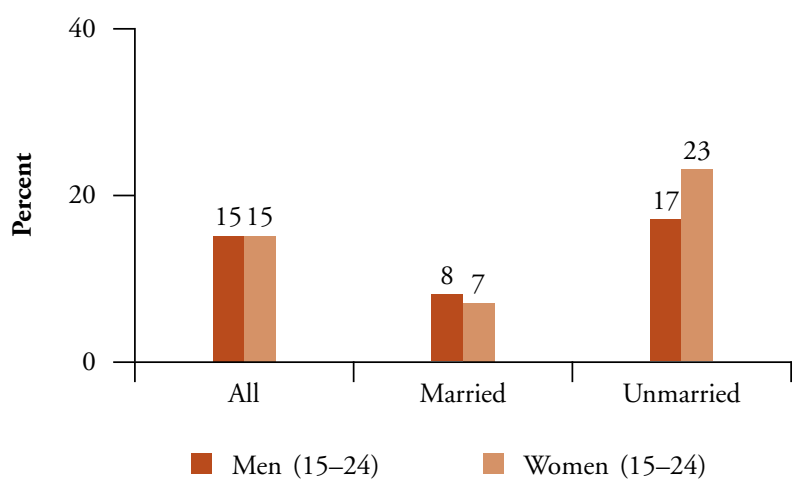

Source: International Institute for Population Sciences and Population Council, 2010. 
The Adolescence Education Programme (AEP) and other similar programmes under the National Adolescent Reproductive and Sexual Health Strategy hold much promise. Unfortunately, reports suggest that they have been unevenly implemented and their reach remains limited: just 15 percent of youth have received family life or sex education in school or through special programmes sponsored by the government or NGOs, ranging from less than 10 percent among the married to 17 percent and 23 percent among unmarried young men and women, respectively (Figure 3.4). Further analysis of youth study data indicates that even among those who have completed high school, just 26 percent and 35 percent of young men and women, respectively, had received such education.

Concerns remain, in addition, with regard to the quality of training imparted to the trainers and the extent to which this has succeeded in breaking down traditional inhibitions about discussing sensitive topics. The poor quality of training imparted to trainers and their inhibitions in imparting information on sexual and reproductive matters to students (Verma, Sureender and Guruswamy, 1997) are likely to prevent many teachers from serving as a reliable source of information on these matters. Indeed, the Youth Study reports that just 10 percent of young people had received information on sexual matters from teachers (International Institute for Population Sciences and Population Council, 2010).

Recent revisions of the AEP curriculum have brought in a broader sexual and reproductive health focus than the earlier and narrower HIV focus, and hold promise not only to raise awareness among young people but also to enable young people to correctly understand and assess the risks they face and adopt appropriate protective actions. At the same time, other programmes intended to impart life skills to young people, including, for example, the
Kishori Shakti Yojana (KSY) programme or the Rajiv Gandhi Scheme for Empowerment of Adolescent Girls (the SABLA scheme) and the University Talk AIDS programme, have great potential, but the extent to which the approaches and content of these programmes have been effective and acceptable to young people has not received much attention.

\section{Outstanding issues in the implementation of programmes to empower girls}

A number of programmes have focused on empowering adolescent girls, raising the status of the girl child, and changing gender norms. Concerns have been raised about the implementation of these programmes. For example, conditional cash transfer programmes intended to raise the status of the girl child have been fraught with cumbersome eligibility criteria and conditionalities, lack of clarity, limited community involvement, and unattractive benefits (Sekher, 2010). The extent to which programmes for adolescent girls, notably the KSY/ SABLA programme, have resulted in significant improvements in girls' nutritional levels, acquisition of marketable skills or awareness and agency is not yet clear. In a number of these programmes, fewer girls have been reached than was anticipated, and the achievement of annual targets has been erratic. Indeed, resources allocated for various programmes for girls are severely under-utilised (Planning Commission, 2011).

\section{Health system limitations}

A number of health system limitations have been noted that compromise young people's ability to attain high standards of sexual and reproductive health.

Adolescent health clinics are functional in many states, but are concentrated in a few (Gujarat, Madhya Pradesh, Maharashtra, Himachal Pradesh, 
Kerala and Punjab; Ministry of Health and Family Welfare, 2009b). Moreover, the few evaluations available suggest that the programme has neither improved access to services among youth nor the quality of services they receive. Evidence from an evaluation of 21 Adolescent Reproductive and Sexual Health (ARSH) clinics/centres in Gujarat observes that not all were functional; very few had separate OPD hours and days designated for adolescents or provided auditory and visual privacy; few young people were aware of the clinics and even fewer would use them because of lack of privacy; fear of attending clinics located in health centres and hospitals, and fear of provider attitudes (Centre for Operations Research and Training, 2009). Although training programmes on adolescent reproductive and sexual health have been imparted for various levels of providers, not all medical officers, staff nurses, Auxiliary Nurse Midwives (ANMs), Accredited Social Health Activists (ASHAs) and other personnel have been trained, or sensitised about the unique needs of the young (Ministry of Health and Family Welfare, 2009b). Moreover, training has not always combined a focus on the content of information to be imparted with strategies for imparting the information or attention to the clarification of values. Several studies have highlighted that the reach of programmes, including the Janani Suraksha Yojana (JSY) and ASHA programme remains inequitable (Lim et al., 2010; Santhya et al., 2011b). Finally, the poor quality of sexual and reproductive health services in the public sector has been widely observed, including such issues as lack of privacy and confidentiality. Further analysis of Youth Study data has established a link between the quality of care received on previous occasions and treatmentseeking for symptoms of infection: among married women who had experienced one or more symptoms of infection, the quality of previous contacts with health care providers was positively associated with whether or not treatment was sought, even after controlling for confounding factors (AOR 1.29, Sabarwal and Santhya, 2011).

\section{Limited attempts at engaging boys and young men}

While wide gender disparities place young women at a notable disadvantage, young men are also disadvantaged in many ways. Many misuse tobacco products and alcohol, many experience unsafe premarital sex, and notable minorities even marry in adolescence. Further, their awareness of sexual and reproductive health matters is limited, many do not receive family life or sex education, and many, including the married, lack easy access, in practice, to contraceptives from a health care provider or pharmacy. Finally, as noted earlier, many hold unequal gender norms, and power imbalances are evident within marital relations. These findings highlight that young men are vulnerable-albeit in different ways than young women-and argue that programmes for adolescents and young people must be inclusive of boys and young men.

\section{Insufficient attention to reach the most vulnerable and the marginalised}

The evidence presented in this review emphasises the heterogeneity of youth not only in terms of their situation but also with regard to their needs. Also evident is the heightened vulnerability of such subgroups of young people as those growing up in poverty, belonging to socially excluded groups and those who have missed the chance to acquire an acceptable level of schooling. Poverty, social exclusion and lack of education pose significant obstacles to young people's attainment of good sexual and reproductive health and realisation of their rights. Adverse outcomes, for example, early marriage, limited contraceptive use, early childbearing and 
Table 3.7

Differences in indicators of young people's agency, SRH awareness and SRH practices by economic and educational vulnerability, six states, 2006-07

\begin{tabular}{l|c|c|c|c|}
\hline \multirow{2}{*}{$\begin{array}{l}\text { Indicators of agency, awareness and } \\
\text { practices }\end{array}$} & \multicolumn{2}{|c|}{$\begin{array}{c}\text { Men } \\
\text { (15-24 years) }\end{array}$} & \multicolumn{2}{|c|}{$\begin{array}{c}\text { Women } \\
\text { (15-24 years) }\end{array}$} \\
\cline { 2 - 5 } & $\begin{array}{c}\text { Less educated } \\
\text { from poor } \\
\text { households }\end{array}$ & $\begin{array}{c}\text { Better educated } \\
\text { from rich } \\
\text { households }\end{array}$ & $\begin{array}{c}\text { Less educated } \\
\text { from poor } \\
\text { households }\end{array}$ & $\begin{array}{c}\text { Better educated } \\
\text { from rich } \\
\text { households }\end{array}$ \\
\hline $\begin{array}{c}\text { Made independent decisions on personal } \\
\text { matters (\%) }\end{array}$ & 52.6 & 60.8 & 18.7 & 42.5 \\
$\begin{array}{c}\text { Permitted to visit a friend outside the } \\
\text { village/neighbourhood unescorted (\%) }\end{array}$ & - & - & 14.9 & 37.8 \\
$\begin{array}{c}\text { Had comprehensive knowledge of } \\
\text { HIV/AIDS (\%) }\end{array}$ & 14.6 & 67.6 & 7.4 & 52.6 \\
\hline $\begin{array}{c}\text { Initiated sex before marriage by age 18 (\%) } \\
\text { Married before age 18 (among those } \\
\text { aged 18-24) (\%) }\end{array}$ & 17.9 & 9.9 & 4.2 & 15.0 \\
\hline $\begin{array}{c}\text { Among the married, became pregnant for } \\
\text { the first time before age 18 (among } \\
\text { those aged 18-24) (\%) }\end{array}$ & 13.3 & 1.4 & 77.2 & 20.4 \\
\hline
\end{tabular}

Source: Calculated from the Youth in India: Situation and Needs 2006-07 study.

malnutrition, were more prevalent among the poor, the socially excluded and the less educated than among other groups. Further analyses using the Youth Study data also reaffirm the vulnerability of young people, particularly, adolescent and young women faced with the double disadvantage of growing up in poverty and lacking education (Table 3.7). Regardless of the indicator and the sex of young people, those who face the double disadvantage of poverty and limited education were considerably less likely than their bettereducated counterparts from wealthy households to exercise agency and to be informed about sexual and reproductive matters, and more likely to have experienced adverse sexual and reproductive health outcomes, including early pre-marital sexual initiation, early marriage and early childbearing. The differences were starker for young women than young men. Unfortunately, the reach of the programmes has been skewed towards the most advantaged.

\section{Weak enforcement of laws and acts}

India has a range of impressive laws and acts intended to promote young people's sexual and reproductive health and rights. It is discouraging to note that these laws and acts have been systematically violated, and that neither the state nor communities have taken concerted steps to enforce or abide by them. There is little evidence of prosecution of those who have violated these laws (National Crimes Records Bureau, 2010). At the same time, while there have been several NGO efforts to inform communities about these laws and available services, and change attitudes about child 
marriage, domestic violence and sex selection, these efforts have been typically small, their effects have not been well documented, and few have been taken to scale.

\section{Difficulties in breaking down patriarchal norms held by key influentials in the community}

Kinship systems in India continue to be ageand gender-stratified, traditional gender norms persist, and investments in girls at the family and community levels remain relatively limited. Changing deeply-entrenched traditional norms and attitudes requires action on many fronts, and it is not clear that enough effort has been placed on addressing each of the key stakeholders. For example, there is evidence that the socialisation of sons and daughters continues to be gendered. Research has shown, for example, that there continues to be a gender gap in parental aspirations for and investments in the education of their sons versus daughters (Santhya and Jejeebhoy, 2012). Double standards in the socialisation of sons and daughters are also evident, with daughters socialised with many more constraints than sons on mobility, freedom to develop social networks, control over money and so on-disparities that clearly influence girls' ability to exercise informed choice as they grow into adulthood (International Institute for Population Sciences and Population Council, 2010). Family elders-mothers- and fathers-in-law, for examplealso play a powerful role in reinforcing gender inegalitarian norms. Likewise, teachers and health care providers are, in different ways, powerful agents of change, but it is not clear that they play a role in changing traditional gender-hierarchical norms and values. Community leaders are another group of stakeholders who are responsible for the upholding of traditional norms. None of these key stakeholder groups has been convincingly reached. Programmes intended to break down the deeply entrenched patriarchal norms held by all of these groups remain relatively rare, and there is little information available on how successful these efforts have been. There is a considerable need to implement and/or strengthen programmes for key influentials in terms of both reach and content. 


\section{CHAPTER 4}

\section{Summary}

This review has highlighted that although youth constitute a large proportion of the Indian population, and although there are many national programmes that aim to address the needs of the young, youth are, for the most part, unprepared to meet the needs of a globalising world. Of concern is the compromised sexual and reproductive health situation of young people. Early and unsafe entry into sexual life and childbearing, exposure to the risk of unwanted pregnancy and infection, unmet need for contraception, unwanted and sometimes coercive sexual activity, and adverse reproductive health outcomes characterise the life of too many youth in India. Progress has been uneven, and gender gaps persist, with young women more likely than young men to experience adverse sexual and reproductive outcomes. The review also highlights that gaps between rural and urban youth, less and better educated youth, poor and wealthy youth and socially excluded and included youth remain. Youth residing in rural areas, with no or limited education, belonging to economically disadvantaged households and belonging to socially-excluded castes, particularly scheduled tribes were more likely than others to report adverse outcomes and compromised ability and resources to take protective actions.

State-wise differentials indicate a number of patterns. First, young women from northern states fared poorly on most indicators included in our review-early marriage, early childbearing, experience of sexual violence within marriage, contraceptive use, unplanned pregnancies, unmet need and use of maternal health services. Indeed, the situation of young women from Bihar, Chhattisgarh, Jharkhand, Rajasthan, and Uttar Pradesh was notably poor. Second, our review indicates that young women in the north-eastern states were also disadvantaged on several counts; for example, unplanned pregnancies and unmet need for contraceptives were high and utilisation of maternal health services was limited among young women in several north-eastern states. Third, although the situation of youth in southern and western states was better than that of their counterparts in other parts of the country, there are exceptions - early marriage, early childbearing and malnutrition are high in Andhra Pradesh, for example.

This review has outlined a number of barriers at the individual, family and systems levels that exacerbate young people's vulnerability. At the individual level, these include their limited awareness of sexual and reproductive matters and limited agency among young women. At the family level, barriers include limited communication between parents and children, and limited family support on sensitive matters. At the school and college levels, they include limited exposure to sexuality education. Finally, at the health system level, it is clear that services are not youth-friendly; youth are inhibited from accessing services and few are approached by the health system; moreover, the limited available evidence suggests that those who do connect with the health system receive services that are no different from those received by adults, that is, services that do not recognise young people's unique service delivery needs. 
While the sexual and reproductive health needs of adolescents and young people are firmly on the national agenda, much remains to be done before programmes can be said to have responded to meeting their needs. Young people are a heterogeneous group whose situation, vulnerabilities, strengths and needs vary greatly, and programmes will have to address these diverse needs through a multi-sectoral approach. In the sexual and reproductive health arena, efforts are needed that strengthen life skills and sexuality education for those in school and out of school, and that make the health system less threatening to young people. An increasing number of intervention models to build agency and promote egalitarian gender role attitudes among young people have been tested in India.

These models should be reviewed and replicated or scaled up as appropriate. Moreover, programmes will need to address young people's gatekeepers - their parents and families, their teachers and health care providers, and the community at large; these programmes must, for example, ensure that health care providers are less judgemental of young people with sexual health concerns, and that traditional norms held by parents and gatekeepers, policy makers and politicians are broken down. Together, these programme actions will enable young people to make informed and healthy life choices. 


\section{References}

Acharya, R., F. Ram., S. J. Jejeebhoy et al. 2009. Physical and sexual violence within marriage among youth in India: Findings from the Youth in India, Situation and Needs Study. Paper presented at the XXVI IUSSP International Population Conference, Marrakech, Morocco, 27 September-2 October, 2009.

Alexander, M., L. Garda, S. Kanade et al. 2006. Formation of partnerships among women and men in Pune district, Maharashtra. New Delhi: Population Council.

Andrew, G. and V. Patel. 2002. Health Needs of Adolescents: A Study of Health Needs of Adolescents in Higher Secondary Schools in Goa. Alto-Porvorim: Resource Centre for Adolescent and Child Health.

Barua, A. and K. Kurz. 2001. "Reproductive health-seeking by married adolescent girls in Maharashtra, India," Reproductive Health Matters 9(17):53-62.

Chhabra, S., N. Gupte, A. Mehta et al. 1988. "MTP and concurrent contraceptive adoption in rural India," Studies in Family Planning 19(4):244-47.

Centre for Operations Research and Training (CORT). 2009. Assessment of Adolescent Reproductive and Sexual Health (ARSH) Centres in Gujarat-A Report. Vadodara: CORT.

Ganatra, B.R. 2000. "Abortion research in India: What we know and what we need to know," in Women's Reproductive Health in India, eds. R. Ramasubban and S. Jejeebhoy. Jaipur: Rawat Publications.

Ganatra, B.R. and S. Hirve. 2002. "Induced abortions among adolescent women in rural Maharashtra," Reproductive Health Matters 10(19):76-85.

Garda, L. and M. Alexander. 2009. Parent-child connectedness: A pressing need to be addressed in rural and urban India. Paper presented at XXVI IUSSP International Population Conference, Marrakech, Morocco.

International Institute for Population Sciences (IIPS) and Macro International, 2007. National Family Health Survey (NFHS-3), 2005-06: India, Volume 1. Mumbai: IIPS.

International Institute for Population Sciences (IIPS) and Population Council. 2010. Youth in India: Situation and Needs 2006-2007. Mumbai: IIPS.

Jejeebhoy, S.J. and K.G. Santhya. 2011. Parent-child communication on sexual and reproductive health matters: Perspectives of mothers and fathers of youth in India. New Delhi: Population Council.

Jejeebhoy, S.J. and M.P. Sebastian. 2004. "Young people's sexual and reproductive health," in Looking Back, Looking Forward: A Profile of Sexual and Reproductive Health in India, ed. S.J. Jejeebhoy. New Delhi: Rawat Publications.

Jejeebhoy, S.J., S. Kalyanwala., A.J. Francis Zavier et al. 2010. "Experience seeking abortion among unmarried young women in Bihar and Jharkhand, India: delays and disadvantages," Reproductive Health Matters 18(35):163-174.

Lim, S.S., L. Dandona, J.A. Hoisington et al. 2010. "India’s Janani Suraksha Yojana, a conditional cash transfer programme to increase births in health facilities: An impact evaluation,” The Lancet 375 (9730):1939-2050. 
Mahajan, P. and N. Sharma. 2005. "Parents attitude towards imparting sex education to their adolescent girls," Anthropologist 7(3):197-199.

Ministry of Health and Family Welfare (MOHFW). 2009a Reproductive and Sexual Health of Young People in India-Secondary analysis of data from National Family Health Surveys of India-1, 2, 3 (1992-2006) for the age group 15-24 years. New Delhi: MOHFW, Government of India.

Ministry of Health and Family Welfare (MOHFW). 2009b. National Rural Health Mission Reproductive \& Child Health Program Phase II, 6th Joint Review Mission. New Delhi: Donor Coordination Division, MOHFW, Government of India.

National Crimes Records Bureau (NCRB). 2010. Crime in India-2010. New Delhi: Ministry of Home Affairs, Government of India.

National Institute of Medical Statistics and National AIDS Control Organisation (NACO). 2008. National Behavioural Surveillance Survey (BSS), 2006; Youth (15-24 Years). New Delhi: NACO, Ministry of Health and Family Welfare, Government of India. Accessed on 5 January 2009 at $<$ http://www.nacoonline.org/Quick_ Links/Publication/ME_and_Research_Surveillance/Reports_and_Surveys/National_BSS_20062>.

Office of the Registrar General, India. 2011. Special bulletin on maternal mortality in India 2007-09, Sample Registration System. New Delhi: Office of the Registrar General.

Office of the Registrar General and Census Commissioner, India. 2006. Population Projections for India and States 2001-2026 (Revised December 2006). New Delhi: Office of the Registrar General and Census Commissioner.

Parasuraman, S., S. Kishor, S.K. Singh et al. 2009. A Profile of Youth in India, National Family Health Survey (NFHS-3), India, 2006-06. Mumbai: IIPS.

Planning Commission. 2011. Mid-Term Appraisal Eleventh Five Year Plan 2007-2012. New Delhi: Oxford University Press.

Prasad, J.H., S. Abraham, K.M. Kurz et al. 2005. "Reproductive tract infections among young married women in Tamil Nadu, India," International Family Planning Perspectives 31(2):73-82.

Rani, M. and S. Bonu. 2003. "Rural Indian women's care-seeking behavior and choice of provider for gynecological symptoms," Studies in Family Planning 34(3):173-185.

Sabarwal, S and K.G. Santhya. 2011. Treatment-seeking for symptoms of reproductive tract infections among married and unmarried young women in India. (Unpublished paper).

Santhya, K.G. and S.J. Jejeebhoy. 2012. Gender differences in educational attainment among youth in India: An exploratory study of parental aspirations about and investment in young people's schooling. New Delhi: Population Council. (Forthcoming report).

Santhya, K.G., R. Acharya and S.J. Jejeebhoy. 2011. "Condom use before marriage and its correlates: Evidence from India," International Perspectives on Sexual and Reproductive Health 37(4):170-180.

Santhya, K.G., N. Haberland, E. McGrory et al. 2003. Supporting married adolescent girls: encouraging positive partner involvement, paper presented at the meeting Reaching Men to Improve Reproductive Health for All, Washington, September 15-18. 
Santhya, K.G., R. Acharya, S.J. Jejeebhoy et al. 2011a. "Timing of first sex before marriage and its correlates: Evidence from India," Culture Health and Sexuality 13(3):327-341.

Santhya, K.G., S.J. Jejeebhoy, R. Acharya et al. 2011b. Effects of the Janani Suraksha Yojana on maternal and newborn care practices: Women's experiences in Rajasthan. New Delhi: Population Council.

Sekher, T.V. 2010. Special Financial Incentive Schemes for the Girl Child in India: A Review of Select Schemes. Mumbai: IIPS.

Shetty, P., S. Kowli, and V. Patil. nd. Attitude of mothers towards sex education of adolescent girls. Regional Health Forum WHO South-East Asia Region (Volume 3). Accessed on 29 March 2011 at http://www.searo.who.int/en/ Section1243/Section1310/Section1343/Section1344/Section1351/Section1686_7197.htm.

Solapurkar, M.L. and R.N. Sangam. 1985. "Has the MTP Act in India proved beneficial?" Journal of Family Welfare 31(3):46-52.

Soletti, A.B., V. Guilamo-Ramos, D. Burnette et al. 2009. "India-US collaboration to prevent adolescent HIV infection: The feasibility of a family-based HIV-prevention intervention for rural Indian youth," Journal of the International AIDS Society 12:35.

Sujay, R. 2009. "Premarital sexual behaviour amongst unmarried college students of Gujarat, India," Health and Population Innovation Fellowship Programme Working Paper No. 9. New Delhi: Population Council.

Verma R.K, S. Sureender and M. Guruswamy. 1997. "What do school children and teachers in rural Maharashtra think of AIDS and sex?” Health Transition Review 7 (Suppl.): 481-86.

Verma, R.K., J. Pulerwitz, V. Mahendra, et al. 2006. "Challenging the changing gender attitudes among young men in Mumbai, India," Reproductive Health Matters 14(28):135-143. 


\section{Authors}

K G Santhya, Associate II, Population Council, New Delhi

Shireen J Jejeebhoy, Senior Associate, Population Council, New Delhi 

Printed at: Systems Vision; A-199, Okhla Ph I, New Delhi-110020 • email: systemsvision@gmail.com • Ph: 26811195 

(P) Population Council

Zone 5-A, Ground Floor India Habitat Centre

Lodi Road

New Delhi 110 003, India 